WOJCIECH KRIEGSEISEN

Tadeusz Manteuffel Institute of History, Polish Academy of Sciences, Warsaw

\title{
THE HISTORICAL REGION OF EAST-CENTRAL EUROPE IN RESEARCH INTO THE HISTORY OF RELIGION IN THE EARLY MODERN ERA
}

\begin{abstract}
The study contains the reflection on the usefulness of the notion East-Central Europe as a historical region in the research on confessional relations in the early modern era. It begins with the description of the discussion on regionalization of European history, with particular emphasis on the frequently ideologized division into East and West. Next, the author recalls the genesis of the notion of East-Central Europe as a historical region, which was introduced after the Second World War by Oskar Halecki, and the popularization of this notion in the second half of the twentieth century. In the author's opinion, the most important criterion in the evaluation of usefulness of this construct should be its research functionality checked not in syntheses or reviews, but in detailed research into specific problems, including comparative research.
\end{abstract}

Ke y w ords: East-Central Europe, Oskar Halecki, historical regions, denomination relations, comparative studies.

Emanuel Rostworowski, one of the most outstanding Polish researchers of the early modern era, used to say that chronological caesuras are the subject of historians' discussion when they have nothing more interesting to say. Perhaps certain theoretical plots of discussions devoted to historical divisions and regions of Europe can be included in a similar category of 'red herrings', as it seems that deliberations limited to terminological issues or specifying borders of discussing the so called European historical regions do not in themselves have any particular cognitive value and can be practised quite safely, because these are problems that cannot ultimately be solved. Often they refer to discussions in the media, so popular at the end of the twentieth century regarding the affiliation of the countries of 'new Europe' to 'old Europe', that is, the 'real Europe', so to a certain degree they are a continuation 
of the Western European search for the roots and essence of 'European identity' in Western Europe when the institutional foundations of the European community were being constructed. ${ }^{1}$

On the other hand, Polish discussions of this type quite often referred to the old but still vivid tradition of juxtaposing 'our' European freedom with 'their' Asian despotism. ${ }^{2}$ In the more distant past this also had a clear confessional aspect, in which the freedom of European Christians - the subjects of rulers 'by the Grace of God' or even - as in the Polish Kingdom - under a 'power covenant' - were opposed to the enslavement of the subjects of barbarian Orthodox or Islam rulers. This was the foundation of the very popular theory of the 'outpost' of the Christian (later only Catholic) Europe. ${ }^{3}$ It was challenged only by the Enlightenment, which performed a crucial redefinition of ideas related to European culture and civilization, and in Poland initiated self-critical reflection and the growing conviction of the need for modernization, which was often referred to as 'Europeanization'. ${ }^{4}$ Nevertheless, this latter idea resulted in a paradox stressed by Andrzej Wierzbicki - Eastern European societies, in admitting their backwardness and the need to 'catch up with the West', admitted thereby that they did not belong to it. ${ }^{5}$ In this way the complex of 'civilizational youth' of European East in regard to the West emerged, which was so important for Polish thought in the nineteenth century, and which operates even today. ${ }^{6}$

Therefore, it seems that scholarly deliberations on European identity, and, in particular, being part of the specified (more often non-specified) historical regions should be now justified, first of all, in the context

${ }^{1}$ See the bibliography compiled by Rolf-Joachim Sattler: Europa. Geschichte und Aktualität des Begriffes, Braunschweig, 1971, Schriftenreihe des Internationalen Schulbuchinstituts, vol. 16.

${ }^{2}$ Erazm Kuźma, Mit Orientu i kultury Zachodu w literaturze XIX i XX wieku, Szczecin, 1980; Bronisław Geremek, 'Więź i poczucie wspólnoty w średniowiecznej Europie’, in Dziesięć wieków Europy. Studia z dziejów kontynentu, ed. Janusz Żarnowski, Warsaw, 1983, pp. 19-81.

${ }^{3}$ Janusz Tazbir, Polskie przedmurze chrześcijańskiej Europy. Mity a rzeczywistość historyczna, Warsaw, 1987; Andrzej Wierzbicki, Europa w polskiej myśli historycznej i politycznej XIX i XX wieku, Warsaw, 2009, pp. 20-21.

${ }^{4}$ Larry Wolff, Inventing Eastern Europe. The Map of Civilization on the Mind of the Enlightenment, Stanford, CA, 1994, pp. 356-74; Jerzy Michalski, 'Sarmatyzm a europeizacja Polski w XVIII wieku', in idem, Studia historyczne z XVIII i XIX wieku, 2 vols, Warsaw, 2007, vol. 2: Ideologia. Nauka. Historiografia, pp. 7-36.

${ }^{5}$ Wierzbicki, Europa w polskiej myśli historycznej i politycznej, pp. 27-38.

${ }^{6}$ Jerzy Jedlicki, Jakiej cywilizacji Polacy potrzebują. Studia z dziejów idei i wyobraźni XIX wieku, Warsaw, 1988, pp. 19-76, Polska XIX i XX Wieku. Dzieje Społeczne, ed. Janusz Żarnowski. 
of research projects, the goal of which is the solution of particular problems with the use of, for example, comparative research. This also relates to the practice of using the notion of 'Central and Eastern Europe' which is so essential for Polish historiography, and which - since 1950 when Oskar Halecki presented his proposal regarding the division of Europe into four historical regions - has been discussed many times. ${ }^{7}$ Its popularization in the 1980s, when events in the societies of this part of Europe striving to liberate themselves from Soviet domination were in the focus of European attention, was probably mostly due to the dissertation by the Hungarian historian Jenő Szücs, published initially in Hungarian, but quickly translated into English and French. ${ }^{8}$ Szücs proposed to consider as the Central and Eastern Europe region the territories located east of the old border of Carolingian state, that is, the line of the Elbe-Saale-Leitha rivers and the western border of Pannonia, and north west of the lands on the lower Danube. Further to the north, this putative region was bordered by the Eastern Carpathians and then along the notional line dividing western from eastern Slavs. ${ }^{9}$

The German contribution into the theory of research on Central and Eastern Europe is also worth recalling. Here we mainly think about the works of one of the most outstanding contemporary German historians, Klaus Zernack, which are so important for strengthening and deepening the historical region concept developed by Halecki, and eliminating the nationalistic and imperialistic tradition of presenting the history (histories) of Eastern Europe, and also Zernack's edition of

${ }^{7}$ Oskar Halecki, The Limits and Divisions of European History, New York, 1950; in Polish: idem, Historia Europy - jej granice i podziały, transl. Jan M. Kłoczowski, ed. Hubert Łaszkiewicz, introduction Jerzy Kłoczowski, Lublin, 1994, Biblioteka Europy Środkowo-Wschodniej, vol. 1 (2nd edn Lublin, 2002). On the genesis and significance of Halecki's proposal see, for a recent example, Hans-Jürgen Bömelburg, 'Zwischen imperialer Geschichte und Ostmitteleuropa als Geschichtsregion. Oskar Halecki und die polnische "jagiellonische Idee"', in Vergangene Größe und Ohnmacht in Ostmitteleuropa. Repräsentationen imperialer Erfahrung in der Historiographie seit 1918, ed. Frank Hadler and Matthias Mesenhöller, Leipzig, 2007, pp. 99-133; Piotr S. Wandycz, 'Oskar Halecki i jego koncepcja Europy Środkowo-Wschodniej', Rocznik Instytutu Europy Środkowo-Wschodniej, 5, 2007, pp. 45-51; Marek Kornat, 'Historyk Europy Środkowo-Wschodniej. Oskar Halecki (1891-1973) w nauce i życiu Polski', in Historik v proměnách doby a prostředí 20. století, ed. Jiří Hanuš and Radomír Vlček, Brno, 2009, pp. 305-38.

${ }^{8}$ Jenő Szűcs, 'Vázlat Európa három történeti régiójáról', Történelmi Szemle, 1981, 3, pp. 313-59; idem, 'The Three Historical Regions of Europe', Acta Historica Academiae Scientiarum Hungaricae, 29, 1983, 2/4, pp. 131-84; idem, Les trois Europes, introduction Fernand Braudel, Paris, 1985.

${ }_{9}$ Idem, Trzy Europy, transl. Jan M. Kłoczowski, scientific ed. Hubert Łaszkiewicz, introduction Jerzy Kłoczowski, Lublin, 1995, Biblioteka Europy Środkowo-Wschodniej, vol. 2, pp. 29-34. 
Werner Conze's book. ${ }^{10}$ According to the latter's theory, early modern Central and Eastern Europe covered the broadly understood Bohemian, Hungarian, and Polish territories together with the Grand Duchy of Lithuania, Livonia and Pomerania. In the further part of this article we will refer to the concepts of other German researchers active in this field, especially Gottfried Schramm and Michael G. Müller.

Basically we may state that the notion of the Central and Eastern European historical region has been accepted not only in Polish scholarly terminology but also in that used by our neighbours. ${ }^{11}$ Perhaps the best proof of this is the change of the title of a scientific magazine published by the Herder Institute in Marburg, which until 1994 had the title Zeitschrift für Ostforschung and since that year has been published as Zeitschrift für Ostmitteleuropa-Forschung, and the area of the main interest relates to the history and culture in the present territories of Poland, Czechia, Slovakia, Belarus, Ukraine, Lithuania, Latvia and Estonia. ${ }^{12}$ A year later a research centre was established in Leipzig (Geisteswissenschaftliches Zentrum Geschichte und Kultur Ostmitteleuropas), which in the period 1992-95 was active in Berlin as Forschungsschwerpunkt Geschichte und Kultur Ostmitteleuropas, and now is closely connected with Leipzig University, the task of which is conducting research on the history and culture of Central and Eastern Europe broadly defined as the area between the Baltic, Black and Adriatic Seas. ${ }^{13}$

Obviously, the works of Polish researchers publishing in Poland and in emigration have been decisive for contemporary Polish historiography. As early as in 1985 Bronisław Geremek published deliberations on Poland

${ }^{10}$ Klaus Zernack, Osteuropa. Eine Einführung in seine Geschichte, Munich, 1977; compare also this author's deliberations on the notion of North-Eastern Europe: idem, 'Główne problemy historii północno-wschodniej Europy', ZH, 50, 1985, 4, pp. 25-38; Werner Conze, Ostmitteleuropa. Von der Spätantike bis zum 18. Jahrhundert, ed. and afterword Klaus Zernack, Munich, 1992, pp. 105-42. Conze, who died in 1986, was a controversial person, he had a Nazi past, but his achievements after 1945 are worth noticing, see: Götz Aly, 'Theodor Schieder, Werner Conze oder die Vorstufen der physischen Vernichtung', in Deutsche Historiker im Nationalsozialismus, ed. Winfried Schulze and Otto Gerhard Oexle, Frankfurt am Main, 1999, pp.163-82 and Thomas Etzemüller, Sozialgeschichte als politische Geschichte. Werner Conze und die Neuorientierung der westdeutschen Geschichtswissenschaft nach 1945, Munich, 2001.

${ }^{11}$ Jerzy Kłoczowski, Europa Środkowowschodnia w historiografii krajów regionu, Lublin, 1993, Materiały Instytutu Europy Środkowo-Wschodniej [Materials of the Institute of East-Central Europe], vol. 5.

${ }^{12}$ See: 〈https://www.herder-institut.de/servicebereiche/verlag/zfo-zeitschrift -fuer-ostmitteleuropa-forschung.html $\rangle$ [accessed 13 October 2017]. It is difficult to state to what extent the decision on the change of the title of the magazine was caused by the need to part with the tradition of the negatively perceived - especially in Eastern Europe - 'Ostforschung'.

${ }^{13}$ See: 〈http://research.uni-leipzig.de/gwzo/〉 [accessed 13 October 2017]. 
in the cultural geography of medieval Europe, which were also valuable in this respect, ${ }^{14}$ in 1992 a synthetic book by Piotr Wandycz was published, ${ }^{15}$ and in 1998 Jerzy Kłoczowski's work on 'younger Europe' appeared. ${ }^{16} \mathrm{Nev}-$ ertheless, the greatest merits for popularizing the notion of an East-Central European historical region belong - after 1989 - to the Society of the Institute of East-Central Europe. Since 2001 the Institute of East-Central Europe headed by Jerzy Kłoczowski has been active in Lublin, and since 2003 it has published a Yearbook of the Institute of East-Central Europe edited by him. ${ }^{17}$ The international environment interested not only in the history but also the contemporary times of this region has for a long time been gathered around the Institute and its magazine. ${ }^{18}$

The characteristic features of the aforementioned works and numerous valuable historical publications of the Lublin Institute are synthesis and review. The state of scientific research on detailed and common problems essential for the history of East-Central European societies looks rather different - worse, in fact. The prevalence of synthetic studies over detailed problem-focused studies probably results from the fact that in Polish historiography this notion - being by assumption a research term - still often appears in a metaphorical meaning, to refer to per analogiam to Geremek's deliberations relating to the terminology of social history. ${ }^{19}$ 'Figurativeness' in this case only partly consists in the intended indistinct meaning of certain notions mentioned by Geremek. The specific 'revisionism' of the notion 'East-Central Europe' seems to be more important. It is

${ }^{14}$ Bronisław Geremek, 'Polska w geografii kulturowej średniowiecznej Europy', in Kultura Polski średniowiecznej X-XIII w., ed.Jerzy Dowiat, Warsaw, 1985, pp. 8-26.

${ }^{15}$ Piotr S. Wandycz, The Price of Freedom. A History of East Central Europe from Middle Ages to the Present, London and New York, 1992; Polish translation Cena wolności. Historia Europy Środkowo-Wschodniej od średniowiecza do współczesności, transl. Tomasz Wyrozumski, Cracow, 1995. Similar conceptualization we can find in the recently published collection of this author's works: idem, O czasach dawniejszych i bliższych. Studia z dziejów Polski i Europy Środkowo-Wschodniej, Poznań, 2009.

${ }^{16}$ The title 'younger Europe' is the indistinctly defined East-Central European historical region: 'The corpus of this Europe is historical territories connected with Poland, Bohemia and Hungary, three monarchies formed in the tenth to the twelfth century.' Jerzy Kłoczowski, Młodsza Europa. East-Central Europe w kręgu cywilizacji chrzescijańskiego średniowiecza, Warsaw, 1998, p. 11.

$17\langle$ http://www.iesw.lublin.pl/rocznik/〉 [accessed 13 October 2017].

${ }^{18}$ Kłoczowski, East-Central Europe w historiografii, pp. 33-37.

${ }^{19}$ Geremek considered the occurrence of 'figurative terms' in the historians' conceptual apparatus to be valuable, since the use thereof prevents occurrence of 'the barrier of technical language between the historian and the recipient of historical literature', Bronisław Geremek, 'Uwagi o pojęciu “mas” w historii społecznej', RHum, 34, 1986,2 , p. 199. I believe that one should be very cautious and careful in assessing the balance sheet of benefits and losses resulting from the use of indistinct terms. 
supposed to remind the historians of the 'Western world' of the history of these European societies, which after the Second World War, against their will, found themselves in the orbit of Soviet power. ${ }^{20}$ Insofar as in the case of Halecki and his direct continuators this sui generis 'historical policy' was not only understandable but also estimable, focusing now on this aspect of the problem does not seem to be particularly inspiring and sometimes looks like working off the 'periphery complex' in regard to the 'West'. ${ }^{21}$

It seems that the most important criterion of assessment of the category of historical regions should be the usefulness for research. In studies on the early modern history of the region defined as East-Central Europe it has so far been confirmed mostly for problems of political systems and in studies on political culture. The issues of the economic history of this region, which were much discussed in the mid-twentieth century, now interest scholars less. It is true that about a dozen years ago, Krzysztof Brzechczyn returned to the subject of the economic separateness of Central Europe's development vis-à-vis the 'West', referring to the 'Elbe border' theory and the seigneurial economy based on the manor and serfdom that was supposedly dominant east of it, but his study has a theoretical and methodological character and does not really enrich our knowledge about regional economic processes. ${ }^{22}$

The aforementioned Szücs has already stressed the social system specificities of the East-Central European region with its political elites attached to the order of estates (Ständegesellschaft). It relates, in particular, to Bohemian and Hungarian societies, which from the beginning of the early modern era tried to counteract the centralist trend and, next, the absolutist trend represented by Habsburgs. ${ }^{23}$ We have an analogical, to a certain extent, trend in the Polish Kingdom or Crown, where the estate sys-

${ }^{20}$ Jerzy Kłoczowski, ‘Oskar Halecki i jego walka o miejsce Polski w Europie’, in Z dziejów polityki i dyplomacji polskiej. Studia poświęcone pamięci Edwarda hr. Raczyńskiego, Prezydenta Rzeczypospolitej na wychodźstwie, ed. Henryk Bułhak, Warsaw, 1994, pp. 397-406; Rafał Stobiecki, 'Twórczość emigracyjna Oskara Haleckiego (1891-1973). Próba charakterystyki', in Studia z dziejów Polski i Europy w XIX i XX wieku. Księga dedykowana Profesorowi Piotrowi Stanisławowi Wandyczowi, ed. Janusz Faryś, Roman Nir and Marek Szczerbiński, Gorzów Wielkopolski, 2004, pp. 581-92. See also: Janusz Cisek, Oskar Halecki. Historyk Szermierz Wolności, Warsaw, 2009 and Oskar Halecki i jego wizja Europy, ed. Małgorzata Dąbrowska, 3 vols, Warsaw and Łódź, 2012-14, vol.1.

${ }^{21}$ For example, Elżbieta Znamierowska-Rakk, ‘Pojęcie i tożsamość Europy Środkowo-Wschodniej w historiografii makroregionu i opinie elit Zachodu', SDRE, 45, 2010, pp. 5-20.

${ }^{22}$ Krzysztof Brzechczyn, Odrębność historyczna Europy Środkowej. Studium metodologiczne, Poznań, 1998.

${ }^{23}$ Szücs, Trzy Europy, p. 88 ff. 
tem transformed itself in the sixteenth century into the so called noble democracy (demokracja szlachecka). The fear concerning the strengthening of royal power as in Hungary after the 'bad compromise' of the Hungarian nobility with the Habsburgs in 1526, or even the fear of 'absolutum dominium' - as in Bohemia after the defeat of the estates in $1620-$ until the end of the eighteenth century is one of the characteristic features of the political culture of the Polish-Lithuanian nobiliary system. ${ }^{24}$

This concept focusing on political problems was developed in the 1980s by the aforementioned Schramm, who opted for the thesis that the specific type of political culture, separate both from the East and from the West and developed after 1500, common for Polish, Bohemian and Hungarian noblemen, constitutes an example of European regional culture. The conclusion of these deliberations referred to the thesis - much discussed in the past - of the 'natural' or 'typical' development of European political systems of the early-modern era from the estate system to absolutism. ${ }^{25}$ Schramm is of the opinion that the estate system was not necessarily only a transitional form of system which led to early absolutism. ${ }^{26}$

${ }^{24}$ Stanisław Russocki, 'Monarchie stanowe środkowo-wschodniej Europy XVXVII wieku', KH, 84, 1977, 1, pp. 73-92; Edward Opaliński, Kultura polityczna szlachty polskiej w latach 1587-1652. System parlamentarny a społeczeństwo obywatelskie, Warsaw, 1995, pp. 108-09; Anna Grześkowiak-Krwawicz, Regina libertas. Wolność w polskiej myśli politycznej XVIII wieku, Gdańsk, 2006, pp. 189-214; Urszula Augustyniak, Historia Polski 1572-1795, Warsaw, 2008, pp. 193, 533, 586. Both the latter works are also available in shortened English editions.

${ }^{25}$ See, for example: Walther Hubatsch, Das Zeitalter des Absolutismus 1600-1789, Braunschweig, 1962; Nicholas Henshall, The Myth of Absolutism. Change and Continuity in Early Modern European Monarchy, London and New York, 1992; Heinz Duchhardt, " AAbsolutismus” - Abschied von einem Epochenbegriff?', HZ, 258, 1994, pp.113-22; Der Absolutismus - ein Mythos? Strukturwandel monarchischer Herrschaft in West- und Mitteleuropa (ca.1550-1700), ed. Ronald G. Asch and Heinz Duchhardt, Cologne, 1996.

${ }^{26}$ The first version was presented by the author during the meeting of the Polish and German historians in Mainz in 1984 and next published in Przeglad Historyczny Gottfried Schramm, 'Polen, Böhmen, Ungarn. Übernationale Gemeinsamkeiten in der politischen Kultur des späten Mittelalters und der frühen Neuzeit', PH, 76, 1985, 3, pp. 417-37; see, also: idem, 'Polen - Böhmen - Ungarn. Übernationale Gemeinsamkeiten in der politischen Kultur im 16.-18. Jahrhundert', in Crown, Church and Estates. Central European Politics in the Sixteenth and Seventeenth Centuries, ed. Robert J. W. Evans and Trevor V. Thomas, New York and London, 1991, pp. 176-95 and idem, 'Polen Böhmen - Ungarn. Übernationale Gemeinsamkeiten in der politischen Kultur des späten Mittelalters und der frühen Neuzeit', in Ständefreiheit und Staatsgestaltung in Ostmitteleuropa. Übernationale Gemeinsamkeiten in der politischen Kultur vom 16.- 18. Jahrhundert, ed. Joachim Bahlcke, Hans-Jürgen Bömelburg and Norbert Kersken, Leipzig, 1996, pp. 13-38. We use the Polish edition: Gottfried Schramm, 'Polska - Czechy Węgry. Wspólne cechy kultury politycznej trzech krajów w późnym średniowieczu i wczesnym okresie nowożytnym', in idem, Polska $w$ dziejach Europy Środkowej. Studia, transl. Ewa Płomińska-Krawiec, Poznań, 2010, pp.19-45. 
A good example of the practical research use of such an approach to the problems of the East-Central European estate-states (Ständestaate) is the studies of Austrian, Czech, Netherland, German, Polish and Hungarian historians published in the collective volume published in 1996 in Leipzig in a volume edited by Hans-Jürgen Bömelburg and Norbert Kersken in the series Forschungen zur Geschichte und Kultur des östlichen Mitteleuropa and including an instructive summary by Winfried Eberhard. ${ }^{27}$ These problems were also the subject of a discussion among German historians in Freiburg in 1999. The research usefulness of the term 'East-Central Europe' was confirmed there due to the common nature of the modern historical experience of the countries of St Stephen's Crown, St Wenceslas' Crown (until 1620) and the Polish monarchy mainly with respect to the political system. The rules of the indivisibility of the territory, elective character of the monarchy, domination of the nobility and firm resistance against absolutist attempts made by the monarchy were its decisive factors. Schramm summed up the discussion with a strong statement that East-Central Europe is not the construct of historians and culture researchers but a historical reality most noticeable in the structural similarities of estate-based societies (after 1500), although he also stated the gradual vanishing of these Polish-Bohemian-Hungarian analogies after $1620 .^{28}$

Not long ago, another expert of Polish-German relations, the student of Klaus Zernack, Michael G. Müller, joined the discussion on the research use of the notion of 'East-Central Europe'. Accepting, like Szücs and Zernack, the common and long historical experience of its inhabitants as a necessary condition of a convincing definition of the region, he discussed several examples. Particularly interesting for a modern history scholar is the problem of the seigneurial economy, the phenomenon of durability of the estate system, and the specific culture of East-European Jews. Like Schramm before him, Müller mentions that, nevertheless, none of these phenomena meets the condition of full continuity in time (the early modern era) and exclusiveness in space (East-Central Europe). The problem of the serf-based economy related not only to Bohemia, Hungary and Poland, but also to eastern Germany and Russia. The estate system lasted until the end of the eighteenth century only in nobiliary Poland, and its liquidation in Bohemia in the seventeenth century may even be

${ }^{27}$ Winfried Eberhard, 'Ständische Strukturen in Ostmitteleuropa. Problemstellungen und Thesen. (Eine vorläufige Diskussionsbilanz)', in Ständefreiheit und Staatsgestaltung in Ostmitteleuropa, pp. 311-18.

${ }^{28}$ Gottfried Schramm, “Wokół pojęcia “Europy Środkowo-Wschodniej”. Dyskusja panelowa', in idem, Polska $w$ dziejach, pp. 11-17. 
considered a basis for the later modernization of Bohemian lands. And the cultural formation of the East-European Jewry was characteristic only for the land of the old Polish Kingdom. ${ }^{29}$

Negating the necessity of chronological and spatial continuity of historical phenomena examined in the regional aspect and referring to deliberations by Krzysztof Pomian and Miroslav Hroch, who recently appealed for us to speak about East-Central Europe as a region only in a specific historical context, Müller refers to on every occasion for a 'working' definition of the space analysed by the researcher as a historical region in the context of the specific project. But this would result in the departure in historical narrations not only from the standard 'timeless geographic units' such as continents, states, national and sub- and trans-national regions for 'manifold geographies', and probably also resignation from treating a nation together with its space as the 'natural subject of historiography'. ${ }^{30}$

It is interesting that Müller, an historian with considerable experience in researching confessional relations in early modern East-Central Europe, did not turn his attention to this aspect of regional history. And yet it seems that besides seigneurial economy and estate-based system it is the high level of the religious and confessional diversity which is one of the most characteristic and permanent features of East-Central Europe societies. The old tradition of religious diversity and the high level of confessional freedoms connected with the estate-based system is most frequently mentioned as the specific feature of the Polish-Lithuanian, multi-ethnic and multi-cultural Polish Commonwealth of the nobility. ${ }^{31}$

Kłoczowski was right to extend this characteristic to the whole region:

The sixteenth century may be considered the period of such co-existence in the whole territory of East-Central Europe, when in comparison with confessional western absolutisms and eastern ones of various confessions the purposefully formulated rule of religious freedom and respect for own choices was so meaningful in the life of Bohemian, Hungarian societies or numerous nations gathered in the Polish-Lithuanian-Ruthenian

${ }^{29}$ Michael G. Müller, 'Where and When was (East) Central Europe?', in Domains and Divisions of European History, ed. Jóhann P. Árnason and Natalie J. Doyle, Liverpool, 2010, pp. 112-25; we use the Polish edition: idem, 'Gdzie i kiedy była Europa Środkowo (Wschodnia)?', transl. Jacek Serwański, in idem, Zrozumieć polska historię, Poznań, 2012, pp. 90-105.

${ }^{30}$ Müller, ‘Gdzie i kiedy była Europa Środkowo (Wschodnia)?', pp. 103-105; compare: Krzysztof Pomian, 'L’Europe Centrale. Essai de définition', Revue germanique internationale, 1, 1994, pp. 9-23; Miroslav Hroch, 'Central Europe. The Rise and Fall of an Historical Region', in Central Europe. Core or Periphery?, ed. Christopher Lord, Copenhagen, 2000, pp. 21-34.

${ }^{31}$ Conze, Ostmitteleuropa, p. 127. 
Commonwealth, including Jews. [...] However, it should be remembered that this sixteenth-century situation was very well prepared thanks to the solutions, which had earlier elbowed their way with the greatest difficulty and resistance from various sides. ${ }^{32}$

The Lublin historian means not only the Orthodox religion in the Polish Crown and Grand Duchy of Lithuania and in Transylvania, but also Bohemian Hussitism. ${ }^{33}$ Multi-confessionalism as a feature characteristic for the region was also mentioned by Werner Conze, and although he concentrated more on the consequences of Reformation, he, nevertheless, stressed the earlier presence here of the Orthodox church and Hussitism. ${ }^{34}$

Let us then look closer at this problem in order to state whether religious and confessional diversity may be considered a feature characteristic for East-Central Europe. Let us start with the Polish Kingdom, in the early modern era of the north-western part of the East-Central European historical region. It is interesting that in the late Middle Ages it still had relatively uniform religious characteristics. Besides not very numerous groups of the Jewish middle class gathered in several centres, the most important of which was the capital of $\mathrm{Cracow}^{35}{ }^{35}$ Roman Catholic Christianity dominated here. Changes in this respect began only in the mid-fourteenth century, when the Kingdom of Poland began to expand to the south-east. The process of annexing Halicz Rus' (Ruthenia), which commenced about 1340, led to incorporation of extensive territories, which in the later Commonwealth constituted the palatinate of Ruthenia with its capital in Lwów (Lviv). A large part of Volhynia and Podolia also fell under the rule of King Casimir the Great (1333-70). These territories were inhabited for the most part by a Ruthenian population of the Orthodox confession, and even the intensive - under Polish rule - inflow of immi-

32 'Wiek XVI można uznać za okres takiego współistnienia na całym terenie Europy Środkowo-Wschodniej, kiedy w zestawieniu z absolutyzmami konfesyjnymi zachodnimi i wschodnimi różnych denominacji świadomie sformułowana zasada wolności religijnej i poszanowania dla własnych wyborów miała tak istotne znaczenie w życiu społeczności czeskich, węgierskich, czy licznych ludów skupionych w Rzeczypospolitej polsko-litewsko-ruskiej z Żydami włącznie. [...] Trzeba jednak przypomnieć, że ta szesnastowieczna sytuacja była bardzo solidnie przygotowana dzięki rozwiązaniom, które z największym trudem, z oporami wychodzącymi od różnych stron, torowały sobie drogę wcześniej.', Kłoczowski, Młodsza Europa, p. 311.

${ }^{33}$ Ibid., pp. 315-24.

${ }^{34}$ Conze, Ostmitteleuropa, pp. 167-218.

${ }^{35}$ Recently, on this subject Hanna Zaremska, Żydzi w średniowiecznej Polsce. Gmina krakowska, Warsaw, 2011; see also: Zdzisław Noga, 'Zróżnicowanie etniczne i wyznaniowe mieszczaństwa krakowskiego w XVI wieku’, in Między Zachodem a Wschodem. Etniczne, kulturowe i religijne pogranicza Rzeczypospolitej w XVI-XVIII wieku, ed. Krzysztof Mikulski and Agnieszka Zielińska-Nowicka, Toruń, 2005, pp. 121-28. 
grants of other confessions and religions could not quickly lead to radical changes this respect. Consequently, the rulers of the Polish Kingdom had to respect the followers of the Eastern Orthodox Church and their religious and cultural specificities, first of all, the ecclesiastical structures of Eastern Christianity which were well rooted in Rus'. ${ }^{36}$

Evidence of the limited effects of integration process may be found in the maintenance in the first half of the sixteenth century in the palatinate of Ruthenia of restrictions on the Eastern Orthodox religious cult, principally on Orthodox church construction, discrimination of the Orthodox faithful in access to state and municipal dignities and positions, and even the tendency to treat them as non-Christians - two hundred years after the province's incorporation into the Kingdom of Poland. We do not know whether the confessional and ethnic mosaic in Ruthenia at the beginning of the modern era consisted of many groups separated pursuant to the 'segregation' law, or perhaps it was, after all, a community in statu nascendi, slowly integrating itself to become a multi-ethnic and multi-confessional society. Alternatively, since the theoretical construct of a 'multicultural society' still may arouse doubts, do we deal with the poorly recognized processes characteristic for these regions, which are defined as 'transcultural communication zones'? Literature on these problems has become more numerous in the recent years. ${ }^{37}$

It has also long been known that in many research situations it is preferable to study the idea of 'the zone' to linear borders. ${ }^{38}$ Tadeusz Manteuffel proposed this with respect to historical geography as early as 1929. ${ }^{39}$ Abandoning the notion of linear borders for transitional zones

${ }^{36}$ Jan Drabina, ‘Koegzystencja religii i wyznań w Polsce w latach 1333-1370', Zeszyty Naukowe UJ, Studia Religiologica, 25, 1992, pp. 37-50; Andrzej Janeczek, 'Ethnicity, Religious Disparity and the Formation of the Multicultural Society of Red Ruthenia in the late Middle Ages', in On the Frontier of Latin Europe. Integration and Segregation in Red Ruthenia, 1350-1600, ed. Thomas Wünsch and Andrzej Janeczek, Warsaw, 2004, pp. 15-46.

${ }^{37}$ Literature on the specifics of the Polish-Ruthenia border land, see: Bogumit Szady, Geografia struktur religijnych $i$ wyznaniowych $w$ Koronie w II połowie XVIII wieku, Lublin, 2010, pp. 48-108; Wiesław Romanowicz, 'Pogranicze jako przedmiot badań społecznych', Rozprawy Naukowe Państwowej Szkoły Wyższej im. Papieża Jana Pawła II w Białej Podlaskiej, 1, 2007, pp. 87-97; 'Granice' i 'pogranicza' w badaniach historycznych i antropologicznych, ed. Paweł Figurski and Maksymilian Sas, Warsaw, 2012; Pogranicza kulturowe $w$ Europie średniowiecznej. Słowianie i ich sasiedzi, ed. Kazimierz Grążawski and Marek Dulinicz, Brodnica, Warsaw and Olsztyn, 2012.

${ }^{38}$ See, for example: Grzegorz Myśliwski, 'Powstanie i rozwój granicy liniowej na Mazowszu (XII-poł. XVI w.)', KH, 101, 1994, 3, pp. 3-24.

39 Tadeusz Manteuffel, ‘Metoda oznaczania granic w geografii historycznej’, in Księga pamiątkowa ku uczczeniu dwudziestopięcioletniej działalności naukowej prof. Marcelego Handelsmana, Warsaw, 1929, pp. 221-28. 
would confirm, in any case, the immanent 'ambiguity' of historical regions, so it would comply with the postulate made by Müller, referenced above, and examine them not exactly as geographical regions, but as 'historical spaces' constructed ad hoc for research purposes. ${ }^{40}$

The second important factor which decided about the multi-confessional character of early modern Poland was, obviously, the Polish-Lithuanian Union. The Grand Duchy of Lithuania, the western, Lithuanian and Belarusian territories of which create the north-eastern part of the region, already had in the Middle Ages completely different confessional characteristics from the Kingdom of Poland. Earlier than Poland - at the end of the thirteenth century - Lithuania began to subdue Rus'ian lands. After the annexation of most of Volhynia, Podolia and the lands belonging to Kiev (Kyiv) and Smolensk in the fourteenth century, first the pagan and then Catholic Lithuanians became the ruling religious minority in a state inhabited mainly by Orthodox Ruthenians ${ }^{41}$ who in the mid-sixteenth century still constituted about 75 per cent of the whole population. Taking into account the constant threat from Muscovy, this was a serious problem for the Grand Duchy of Lithuania, so the process of equalizing the political rights of Catholics and Eastern Orthodox Church believers began as early as the first half of the fifteenth century. In the middle of the following century, in the political magnate elite of Lithuanian state Orthodox believers constituted approximately 40 per cent. ${ }^{42}$ Finally, in the 1560s Sigismund Augustus annulled the regulations limiting political rights of Orthodox believers, and this step was confirmed by the provisions of the Lublin Union of $1569 .{ }^{43}$

${ }^{40}$ Michael G. Müller, Cornelius Torp, 'Conceptualising Transnational Spaces of History', European Review of History - Revue européenne d'histoire, 16, 2009, 5, pp. 609-17.

${ }^{41}$ Witold Kamieniecki, 'Ograniczenia wyznaniowe w prawodawstwie Wielkiego Księstwa Litewskiego', PH, 13, 1911,3, pp. 268-82; Tadeusz Śliwa, 'Kościół prawosławny w państwie litewskim w XIII-XIV wieku', in Chrzest Litwy. Geneza, przebieg, konsekwencje, ed. Marek T. Zahajkiewicz, Lublin, 1990, pp. 15-32; compare: Zigmantas Kiaupa, Jūratė Kiaupienè and Albinas Kuncevičius, The History of Lithuania before 1795, Vilnius, 2000 , pp. 72-97.

${ }^{42}$ Marzena Liedke, 'Świadomość narodowa i udział szlachty oraz możnych ruskich Wielkiego Księstwa Litewskiego w kształtowaniu narodu szlacheckiego Rzeczypospolitej w drugiej połowie XVI wieku', in Europa Orientalis. Polska i jej wschodni sasiedzi od średniowiecza po wspótczesność. Studia i materiały ofiarowane Profesorowi Stanisławowi Alexandrowiczowi w 65. rocznice urodzin, ed. Zbigniew Karpus, Tadeusz Kempa and Dorota Michaluk, Toruń, 1996, pp. 135-44; Hieronim Grala, 'Kołpak Witoldowy czy czapka Monomacha? Dylematy wyznawców prawosławia w monarchii ostatnich Jagiellonów', in Katolicyzm w Rosji i prawosławie w Polsce (XI-XX w.), ed. Juliusz Bardach and Teresa Chynczewska-Hennel, Warsaw, 1997, pp. 51-67.

${ }^{43}$ Wiktor Czermak, Sprawa równouprawnienia schizmatyków i katolików na Litwie 
Therefore, in the first half of the sixteenth century, when the ferment of the Reformation ferment reached the Kingdom of Poland and then the Grand Duchy of Lithuania and led to subsequent confessional divisions, the political elites of these countries and a significant part of their inhabitants had for a long time been used to confessional diversity and its practical consequences in culture, politics, religious and everyday life. This must have had a material meaning for the further development of inter-confessional relations in these territories, but it should not be treated as a phenomenon characteristic only for the Polish-Lithuanian state. An analogous, tradition of early modern confessional diversity, albeit of different origins can be observed in the lands of the Crown of St Wenceslas, that is in Bohemia and connected territories: Moravia, the Lower and Upper Lusatia margraviates and the Silesian duchies, which until the mid-eighteenth century constituted under the Habsburg rule a large territorial unit in the south-western part of the region. ${ }^{44}$

One of the most characteristic features of societies in the Bohemian lands societies in the late medieval period was their religious variety. The Prague and Basel Compacts, which ended the Hussite Wars, legalized the existence of a church organization separate from the Roman Catholic Church, the so called Taborites or Utraquist Church. The Czech liturgy involved communion sub utraque specie, there was no episcopal hierarchy, and the clergy could not possess real estate. It is also worth mentioning that as a result of the Hussite revolution, the clergy in Bohemian Crown lost their separate status - the Bohemian estates made decisions at their parliamentary assemblies without clerical representation. ${ }^{45}$ Initially, at least, the division between Catholics and Utraquists was not clear, and the spiritual leader of Utraquists Jan Rokyčana was elected archbishop of Prague. ${ }^{46}$ But his successors had only the title of Utraquist Church administrators and relations with Catholics were finally regulated pursuant to Kutna Hora Agreement in $1485 .{ }^{47}$

(1432-1563), Cracow, 1903; Kazimierz Chodynicki, ‘Geneza równouprawnienia schizmatyków w Wielkim Księstwie Litewskim. Stosunek Zygmunta Augusta do wyznania grecko-wschodniego', PH, 22, 1919-20, pp. 54-135.

${ }^{44}$ František Machilek, 'Böhmen', in Die Territorien des Reichs im Zeitalter der Reformation und Konfessionalisierung. Land und Konfession 1500-1650, ed. Anton Schindling and Walter Ziegler, Münster, 1989, pp. 134-52.

${ }^{45}$ Russocki, 'Monarchie stanowe środkowo-wschodniej Europy', p. 77.

${ }^{46}$ Wojciech Iwańczak, 'Katolicy i husyci w czasach Jerzego z Podiebradu', in Stosunki międzywyznaniowe w Europie Środkowej i Wschodniej w XIV-XVII wieku, ed. Marian Dygo, Sławomir Gawlas and Hieronim Grala, Warsaw, 2002, pp. 25-37.

${ }^{47}$ Winfried Eberhard, 'Entstehungsbedingungen für öffentliche Toleranz am Beispiel des Kuttenberger Religionsfrieden von 1485', Communio viatorum, 29, 1986, pp. 129-54; 
Thus, the reception of the idea of an evangelical reformation in the sixteenth century developed in a society, which had already been divided with respect to confession; first into Catholics and Utraquists, and next, also into Lutherans and followers of a much more radical theological tendency - the Bohemian Brethren (Unitas fratrum, Jednota bratři českých). ${ }^{48}$ On the other hand, as early as the 1520 s and 1530 s, a substantial part of the Utraquists (the so called neo-Utraquists) tried to reach an agreement with Lutherans. ${ }^{49}$ But the most serious problem for Ferdinand I Habsburg (1526-64) and for his successors turned out to be the growing strength of the Bohemian Brethren, which played a leading role in the policy of the Bohemian estates after the outbreak of the Schmalkaldic War in $1546 .{ }^{50}$ In spite of repressions in the following years the Bohemian Brethren won numerous followers among Bohemian and Moravian nobles and magnates. ${ }^{51}$ Consequently, it became the most important tendency in Christianity in the Bohemian Crown, and the reception by the Bohemian Brethren of Calvinism in the second half of the sixteenth century allowed them to play at the beginning of the next century an important role in Bohemian, and even European politics. ${ }^{52}$

The third large territory forming in the East-Central European region in the early modern era - the Crown of St Stephen, encompassing the Kingdom of Hungary with Upper Hungary (Slovakia), Croatia, Transylvania, Bačka, the Banat and the Burgenland, was also settled in the late Middle Ages by the communities very differentiated in ethnic, lan-

idem, 'Zu den politischen und ideologischen Bedingungen öffentlicher Toleranz. Der Kuttenberger Religionsfrieden', Studia Germano-Polonica, 1, 1992, pp.101-18.

${ }^{48}$ František Hrubý, 'Luterství a kalvinismus na Moravě před Bílou horou', Český časopis historický, 41, 1935, pp. 1-40, 237-68; Josef Válka, 'Tolerance, či koexistence? (K povaze soužití různých náboženských vyznání v českých zemích v 15. až 17. století)', Studia Comeniana et historica, 18, 1988, 35, pp. 63-75; Wojciech Iwańczak, 'Kościół w Czechach w XVI w. - dezintegracja i łączność', PHum, 50, 2006, 3, pp. 21-30.

${ }^{49}$ František Hrubý, 'Luterství a novoutrakvismus v českých zemích v 16. a 17. století', Český časopis historický, 45, 1939, pp. 31-44; Zdeněk V. David, Finding the Middle Way. The Utraquist's Liberal Challenge to Rome and Luther, Washigton, DC, Baltimore, MD, and London, 2003, pp. 139-42.

${ }^{50}$ Alfred Kohler, 'Ferdinand I and the Estates. Between Confrontation and Cooperation, 1521-1564', in Crown, Church and Estates, pp. 48-57; Joachim Bahlcke, Regionalismus und Staatsintegration im Widerstreit. Die Länder der Böhmischen Krone im ersten Jahrhundert der Habsburgermonarchie (1526-1619), Munich, 1994, pp. 127-48.

${ }^{51}$ Vázlav Bưžek, Nižší šlechta v politickém systému a kultuře předbělohorských Čech, Praha, 1996, pp. 129-61; Zdeněk Vybíral, Politické komunikace aristokratické společnosti českých zemí na počátku novověku, České Budějovice, 2005, pp. 122-76.

${ }^{52}$ Robert J.W. Evans, The making of the Habsburg Monarchy, 1550-1700. An Interpretation, Oxford, 1984, pp. 206-07; Jaroslav Pánek, Stavovská opozice a její zápas s Habsburky 1547-1577. K politické krizi feudální tř́dy v předbělohorském českém státě, Praha, 1982. 
guage and religion. The eastern and south-eastern territories (Transylvania, the Banat) were inhabited by particularly large groups of Orthodox Christians (Ruthenians, Vlachs, Bulgarians and Serbs). ${ }^{53}$

As a result of Ottoman expansion with the seizure of Belgrade in 1521 and the spectacular victory of Sultan Suleiman I over King Louis II of Hungary and Bohemia at Mohács in 1526, the lands of the Crown of St Stephen's Crown were in 1541 divided into two zones of influence: Ottoman (central Hungary, Transylvania, Bačka, Banat) and Habsburg (north-west Hungary and the Burgenland, Upper Hungary, Croatia). The religious situation was additionally complicated through migration processes and the growing influence of different Evangelical confessions. ${ }^{54}$ In the second half of the sixteenth century the most important was the Evangelical-Reformed confession. The religious structures of Calvinism dominated for some time in Hungary proper and in Transylvania. ${ }^{55}$ On the other hand, in Upper Hungary, especially among Slovaks living there, but also among the German-language Saxons in Transylvania the Evangelical-Augsburg confession strengthened its influence. ${ }^{56}$ And last but not least, Anti-Trinitarism (Unitarianism) was an important factor in these areas, and its main centres were formed mostly among the Hungarian population in Transylvania. ${ }^{57}$ Taking into account the representatives of other religions, primarily Muslims and Jews, it should be stated that the lands of the Crown of St Stephen, under the influence of the Ottoman Turks and the Habsburgs alike, constituted in the early modern era an example of a religious and confessional mosaic.

${ }^{53}$ Márta Fata, Ungarn, das Reich der Stephanskrone, im Zeitalter der Reformation und Konfessionalisierung. Multiethnizität, Land und Konfession 1500 bis 1700, ed. Franz Brendle and Anton Schindling, Münster, 2000, pp. 21-30.

${ }^{54}$ Gabriel Adriányi, 'Die Ausbreitung der Reformation in Ungarn', Ungarn-Jahrbuch, 5, 1973, pp.66-75; David P. Daniel, 'The Influence of the Augsburg Confession in South-East Central Europe', The Sixteenth Century Journal, 11, 1980, pp. 99-114; Ferenc Szakály, 'Türkenherrschaft und Reformation in Ungarn um die Mitte des 16. Jahrhunderts', in Etudes Historiques Hongroises, vol. 2, ed. Ferenc Glatz and Ervin Pamlényi, Budapest, 1985, pp.437-59; Katalin Péter, 'Hungary', in The Reformation in National Context, ed. Bob Scribner, Roy Porter and Mikuláš Teich, Cambridge, 1994, pp. 155-67.

${ }^{55}$ László Révész, 'Die helvetische Reformation in Ungarn', Ungarn-Jahrbuch, 4 , 1972, pp. 72-100; David P. Daniel, 'Calvinism in Hungary. The Ideological and Ecclesiastical Transition to the Reformed Faith', in Calvinism in Europe 1540-1620, ed. Andrew Pettegree, Alastair Duke and Gillian Lewis, Cambridge, 1994, pp. 205-30.

${ }^{56}$ Die Reformation und ihre Wirkungsgeschichte in der Slowakei. Kirchen- und konfessionsgeschichtliche Beiträge, ed. Karl Schwarz and Peter Švorc, Vienna, 1996.

${ }^{57}$ Histoire de la Transylvanie, ed. Béla Köpeczi et al., Budapest, 1989, pp. 280-85; Karl Reinerth, Die Gründung der evangelischen Kirchen in Siebenbürgen, Cologne and Vienna, 1979, Studia Transylvanica, vol. 5; Mihály Balázs, Early Transylvanian Antitrinitarism (1566-1571). From Servet to Paleologus, Baden-Baden, 1996. 
A particularly characteristic feature of confessional relations in the Principality of Transylvania, which formally was in the Turkish zone of influence, was also a high level of mutual toleration, which in the second half of the sixteenth and the first half of the seventeenth century meant equal political rights of representatives of four main Christian confessions: Evangelical-Reformed, Evangelical-Augsburg, Catholic and Anti-Trinitarian. Here we have a clear analogy with inter-confessional relations in the Bohemian lands, especially in Moravia, and in the Polish Commonwealth. The Orthodox Church was in a much worse situation in Transylvania - it was mostly the religion of plebeians and serfs without estate representation, who were, therefore, deprived of political rights..$^{58}$

An important characteristic of religious relations in East-Central Europe was political meaning of 'the second Reformation', understood here as increasing, in the second half of the sixteenth century, the influence of the Evangelical-Reformed confession which pushed Lutheranism from its position as the most important Evangelical confession. Calvinism was becoming at that time the religion of elite magnate and noble groups, which played an important and sometimes decisive role in the Bohemian and Hungarian lands, as well as in the Polish-Lithuanian Commonwealth. The environments of the Bohemian, Hungarian, Polish and Lithuanian Reformed Evangelicals maintained close relationships with their co-believers in Western Europe; they belonged to the international community of Calvinists creating at that time in Europe a kind of 'common religious space' from Transylvania and Grand Duchy of Lithuania to Netherlands and Scotland. ${ }^{59}$ Correspondence, travels and studies in academic centres brought not only scientific, artistic and literary fruit, but also had an influence on the shape and level of political culture of the elites of the East-Central European region. ${ }^{60}$

${ }^{58}$ Ludwig Binder, Grundlagen und Formen der Toleranz in Siebenbürgen bis zur Mitte des 17. Jahrhunderts, Cologne and Vienna, 1976, Siebenbürgisches Archiv, vol. 11; Graeme Murdock, Calvinism on the frontier 1600-1660. International Calvinism and the Reformed Church in Hungary and Transylvania, Oxford, 2000, pp. 110-42.

${ }^{59}$ Frances A. Yates, The Rosicrucian Enlightenment, London and Boston, MA, 1972, we use the Czech translation Rozenkruciánské osvícenství, transl. Martin Konvička, Praha, 2000; Robert J. W. Evans, 'Calvinism in East Central Europe. Hungary and her Neighbours', in International Calvinism 1541-1715, ed. Menna Prestwich, Oxford, 1985, pp.167-96; Murdock, Calvinism on the Frontier, pp. 46-76; János Csohány, 'Die politische Beziehungen von Gábor Bethlen zum reformierten Europa', Jahrbuch für die Geschichte des Protestantismus in Österreich, 110/111, 1994/95, pp. 87-98.

60 Stanisław Tworek, Działalność oświatowo-kulturalna kalwinizmu małopolskiego (połowa XVI - połowa XVIII w.), Lublin, 1970; Amadeo Molnár, 'Reformovaný svět a bratrská šlechta', Křestanská revue, 38, 1971, pp. 140-42; M.E. H. Nicolette Mout, 'Die politi- 
We assume that the intensive reception of Calvinism in the second half of the sixteenth century was connected with the internalizing of political theology.$^{61}$ In spite of the fact that the once popular thesis of the Calvinist roots of parliamentary democracy has not been verified by later research, the importance which Calvin and his continuators attached to the institution of estates representation is undisputable. ${ }^{62}$ This must have been attractive for political elites everywhere where they stood by the ideology of estate freedoms, so also in East-Central Europe. At the end of the sixteenth century the growing threat to estate freedoms in Bohemia, Hungary and the Polish Commonwealth was also strengthened by the will to defend religious freedoms by non-Catholics, and threats came from one source - from the Catholic central authorities, which attempted to weaken the meaning of estate representation and to effect re-Catholicization. ${ }^{63}$ In this situation defenders of political and religious freedoms could refer to this interpretation of the right of resistance which was developed by Western European Calvinists based on Calvin's political doctrine and the so called Evangelical Monarchomachs. ${ }^{64}$ The present state of research on the anti-Habsburg estate opposition in Hungary and Bohemia indicates not only the reception, but also the practical use of this right of resistance

sche Theorie in der Bildung der Eliten. Die Lipsius-Rezeption in Böhmen und Ungarn', in Ständefreiheit und Staatsgestaltung in Ostmitteleuropa, pp. 243-64; Balazs Trencsényi, 'Patriotism and Elect Nationhood in Early Modern Hungarian Political Discourse', in Whose Love of Which Country? Composite States, National Histories and Patriotic Discourses in Early Modern East Central Europe, ed. Balazs Trencsényi and Marton Zászkaliczky, Leiden and Boston, MA, 2010, pp. 499-544.

${ }^{61}$ William R. Stevenson Jr., 'Calvin and Political Issues', in The Cambridge Companion to John Calvin, ed. Donald K. McKim, Cambridge, 2004, pp. 173-87; Andrew Pettegree, 'The Spread of Calvin's Thought', in The Cambridge Companion to John Calvin, pp. 207-24.

${ }^{62}$ Wojciech Kriegseisen, Stosunki wyznaniowe w relacjach państwo-kościół między reformacja a oświeceniem (Rzesza Niemiecka - Niderlandy Pótnocne-Rzeczpospolita polsko-litewska), Warsaw, 2010, pp. 184-90; Władysław J. Stankiewicz, Politics and Religion in Seventeenth Century France. A Study of Political Ideas from the Monarchomachs to Bayle, as Reflected in the Toleration Controversy, Berkeley, 1960, p. 11; Harro Höpfl, The Christian Polity of John Calvin, Cambridge, 1982, pp. 153-58.

${ }^{63}$ Eike Wolgast, Die Religionsfrage als Problem des Widerstandsrechts im 16. Jahrhundert, Heidelberg, 1980; Winfried Schulze, 'Estates and the Problem of Resistance in Theory and Practice in the Sixteenth and Seventeenth Centuries', in Crown, Church and Estates, pp. 158-75.

${ }^{64}$ Kriegseisen, Stosunki wyznaniowe $w$ relacjach państwo-kościót, pp. 190-96; Robert M. Kingdon, 'Calvinism and Resistance Theory 1550-1580', in The Cambridge History of Political Thought, 1450-1700, ed. James H. Burns, Cambridge, 1991, pp. 193-218; compare: Quentin Skinner, The Foundations of Modern Political Thought, 12nd edn, 2 vols, Cambridge, 2005, vol. 2: The Age of Reformation, pp. 302-48. 
doctrine in political struggles at the end of the sixteenth and in the first decades of the seventeenth century. ${ }^{65}$

The situation in the Polish Commonwealth looks rather different, although there were also problems in the relations between the crown and a major part of noble society. In the last decade of the sixteenth century the policy of Sigismund III, which more and more clearly aimed at centralizing power and limiting hitherto equal religious rights, caused a political crisis which had its climax in the period 1606-08 as the so called Sandomierz rebellion (rokosz), also named after its leader, Mikołaj Zebrzydowski. ${ }^{66}$ Yet the functioning in the political culture of the Commonwealth of the modern right of resistance doctrine is not obvious, despite the fact that the influence of Calvinism in shaping in the second half of the sixteenth century has been confirmed ${ }^{67}$ Traditionally, Polish research was rather focused on the medieval genesis of the right of resistance in connection with the formation of the estate-based system. ${ }^{68}$

${ }^{65}$ Kriegseisen, Stosunki wyznaniowe w relacjach państwo-kościót, pp. 198-201,329-31; Jaroslav Pánek, 'The Religious Question and the Political System of Bohemia before and after the Battle of the White Mountain', in Crown, Church and Estates, pp. 129-48; Joachim Bahlcke, 'Calvinism and Estate Liberation Movement in Bohemia and Hungary (1570-1620)', in The Reformation in Eastern and Central Europe, ed. Karin Maag, Aldershot, 1997, pp. 72-91; idem, 'Konföderation und Widerstand. Die politische Beziehungen der böhmischen Ständegemeinde', Folia Historica Bohemica, 13, 1990, pp. 235-88; Kalman Benda, 'Absolutismus und ständischer Widerstand in Ungarn am Anfang des 17. Jahrhunderts', Südostforschung, 33, 1974, pp. 85-124; idem, 'Die Auswirkung der Lehren Calvins auf die Ideologie des ständischen Widerstandes in Ungarn', Jahrbuch der Gesellschaft für die Geschichte des Protestantismus in Österreich, 110/111, 1994/95, pp. 75-85.

${ }^{66}$ Kazimierz Lepszy, Rzeczpospolita Polska w dobie sejmu inkwizycyjnego (1589-1592), Cracow, 1939; Urszula Augustyniak, Wazowie i 'królowie rodacy'. Studium władzy królewskiej w Rzeczypospolitej XVII wieku, Warsaw, 1999, pp. 34-37; Henryk Wisner, 'W imię praw i zwyczajów, czyli wbrew nim. Rokosz Zebrzydowskiego 1606-1607', in Król a prawo stanów do oporu, ed. Mariusz Markiewicz, Edward Opaliński and Ryszard Skowron, Cracow, 2010, pp. 209-21.

${ }^{67}$ Ernst W. Zeeden, 'Calvins Einwirkung auf die Reformation in Polen-Litauen. Eine Studie über den Reformator Calvin im Spiegel seiner polnischen Korrespondenten', in Syntagma Friburgense. Historische Studien Hermann Aubin dargebracht zum 70. Geburtstag am 23.12.1955, ed. Manfred Hellmann, Hans Thieme and Walter Wiora, Lindau and Konstanz, 1956, pp. 329-59; Wojciech Kriegseisen, 'Polski przekład XX rozdziału czwartej części księgi Institutio Christianae religionis Jana Kalwina', OiRP, 50, 2007, pp. 101-13; Kęstutis Daugirdas, 'Rezeption der Theologie Calvins im Großfürstentum Litauen und Königreich Polen', in Calvin und Calvinismus - europäische Perspektiven, ed. Irene Dingel and Herman J. Selderhuis, Göttingen, 2011, pp.155-70.

${ }^{68}$ Józef Szujski, 'Artykuł o wypowiedzeniu posłuszeństwa. Przyczynek do dziejów konstytucji polskiej', in idem, Opowiadania i roztrzasania, vol. 3, Cracow, 1888, pp. 338-60, Dzieła Józefa Szujskiego, series 2, vol. 7; Fryderyk Papée, 'O przywileju mielnickim dla senatu z r. 1501', in Księga pamiatkowa ku czci Oswalda Balzera, vol. 2, ed. Władysław Abraham et al., Lviv, 1925, pp.173-87; Roman Grodecki, 'Do genezy artykułu “o wypowie- 
On the other hand, historians of the early modern era focused on political aspects of non-Catholics' participation in Zebrzydowski's rebellion. ${ }^{69}$

New studies in this respect appeared only recently. Henryk Gmiterek has published some new material, and a few years ago a volume of studies on this problem appeared..$^{70}$ Perhaps new research perspectives regarding the role of the right of resistance in early modern Polish-Lithuanian political culture will be opened by the studies by Maciej Ptaszyński. ${ }^{71}$ Therefore, it seems that the influence of post-Reformation political and legal doctrines in the Polish-Lithuanian Commonwealth and other countries of the region still remains a question yet to be exploited by researchers. It is particularly interesting that in the whole of East-Central Europe, the political ideas of Calvinism at the end of the sixteenth and the beginning of the seventeenth century seem to be an ideology of groups defending the estate-based system against the attempts made by rulers at centralization (therefore - in the traditional meaning - modernization). It is an interesting problem due to the opinion repeated in the literature about Calvinism being a factor strengthening modernization trends. ${ }^{72}$

dzeniu posłuszeństwa"', Przegląd Współczesny, 16, 1937, 61, pp. 185-205; Ludwik Sobolewski and Wacław Uruszczak, 'Artykuły mielnickie z roku 1501', CPH, 42, 1990, pp. 31-61; Jerzy Wyrozumski, 'Od ius resistendi do ius de non praestanda oboedientia w Polsce', in Świat, Europa, mała ojczyzna. Studia ofiarowane profesorowi Stanisławowi Grodziskiemu w 80-lecie urodzin, ed. Marian Małecki, Bielsko-Biała, 2009, pp. 155-64.

${ }^{69}$ Adam Strzelecki, 'Udział i rola różnowierstwa w rokoszu Zebrzydowskiego (1606-1607)', Reformacja w Polsce, 7/8, 1935/36, pp. 101-84; Jarema Maciszewski, Wojna domowa w Polsce (1606-1609). Studium z dziejów walki przeciw kontrreformacji. Część I. Od Stęzycy do Janowca, Wrocław, 1960, p. 279. The problem of the early modern right of resistance (only during the rule of Sigmund August) was only dealt with by Wacław Sobieski, 'Król czy tyran? Idee rokoszowe a różnowiercy za czasów Zygmunta Augusta', Reformacja w Polsce, 4, 1925, pp.1-14.

${ }^{70}$ Henryk Gmiterek, 'Die Rezeption reformatorischer Ideen und religiöser Widerstandstheorien innerhalb der polnischen Eliten', in Ständefreiheit und Staatsgestaltung in Ostmitteleuropa, pp. 217-27; Król a prawo stanów do oporu.

${ }^{71}$ Maciej Ptaszyński, 'Zwischen Gemeinwohl und Staatsräson. Das Widerstandsrecht in den Ständedebatten der polnisch-litauischen Republik im 16. Jahrhundert', in Frühneuzeitliche Reiche in Europa. Empires in Early Modern Europe, ed. Tomasz Gromelski et al., Wiesbaden, 2016, pp. 67-87; idem, 'Debatten um die Grenzen der Herrschaft. Traditionen der Herrscherkritik auf polnischen Reichstagen und deren Wandel im 16./17. Jahrhundert', in Diskussionen über Notwehr, Gegenwehr, Widerstandsrecht und das Gewissen. Normwandel in ständepolitischen Debatten im Europa des 16./17. Jahrhunderts, ed. Luise Schorn-Schütte et al., Frankfurt - in print. I want to thank the author for making his text available.

72 Otto Hintze, 'Kalvinismus und Staatsräson in Brandenburg zu Beginn des 17. Jahrhunderts', Historische Zeitschrift, 144, 1931, pp. 229-86; Gerhard Oestreich, Geist und Gestalt des frühmodernen Staates. Ausgewählte Aufsätze, Berlin, 1969; Peter-Michael Hahn, Calvinismus und Staatsbildung. Brandenburg-Preußen im 17. Jahrhundert, in Territorialstaat und Calvinismus, ed. Meinrad Schaab, Stuttgart, 1993, pp. 239-69. 
Considering the experience of multi-confessionalism and religious co-existence a common value for societies of the region in the longue durée of the early modern era is, nevertheless, impeded by the changes which took place during the Counter-Reformation, which was especially effective in the lands ruled by the Habsburgs, and later also in Poland. The intensive promotion by the rulers of a Catholicism that aspired to return to the position of the ruling (state) religion initiated the process of the Catholicization of political elites, and at the end of the sixteenth and the beginning of the seventeenth century contributed to the crisis of the Polish-Lithuanian non-confessional state. Later in Bohemia the confessional problem was one of the most important reasons for the conflict and fall of the estate-based system of government in 1620. In Hungary, on the other hand, in the second half of the seventeenth century, we notice the accelerated Catholic re-orientation of magnate elites and the reconstruction of the significance of Catholicism. ${ }^{73}$ But the processes of Catholic confessionalization of Bohemian, Hungarian and Polish-Lithuanian societies in the seventeenth century were conditioned differently in each of these territories, and due to this they took place at different speeds and had different effects.

Despite this, in the light of the aforementioned proposals made by Müller, the problem of these discrepancies seems to be less important. A lack of chronological continuity and asymmetry are not reason to exclude the very possibility of studying a phenomenon in the scale of a historical region or an ad hoc constructed Counter-Reformation 'historical space'. Moreover, studying the impact of the Counter-Reformation on the religious and political relations in this region seems particularly requisite due to the fact that in the second half of the twentieth century ideological oppression, particularly strong in the Czechoslovak Socialist Republic, paralysed free reflection in this respect. Only in the 1990s did interesting works of Czech historians appeared, which dealt not only with the problems of re-Catholicization, ${ }^{74}$ but also with the almost completely forgotten question of elites' assimilation to the new political situation after $1620 .^{75}$

${ }^{73}$ Schramm, 'Wokół pojęcia', pp. 16-17.

${ }^{74}$ For example Pavel Balcárek, Kardinál František z Ditrichštejna (1570-1636), Kroměř́ǐ̌, 1990; Josef Honzal, 'Rekatolizace v Čechách. Její historický smysl a význam', Sborník historický, 37, 1990, pp. 37-91; Jiří Mikulec, Pobělohorská rekatolizace v českých zemích, Praha, 1992; Rekatolizace v českých zemích. Sborník př́spěvků z konference v Jičíně konané 10. září 1993, ed.Jindřich Francek, Pardubice, 1995.

${ }^{75}$ Anna Maria Drabek, 'Die politische Haltung der böhmischen und mährischen Stände zum Herrscherabsolutismus des 17. und 18. Jahrhunderts. Von der traditionellen ständischen Rechtspositionen zu frühkonstitutionellen Forderungen', in Ständefreiheit und Staatsgestaltung in Ostmitteleuropa, pp. 265-82; Josef Válka, 'Die "Politiques". 
It is also worth remembering that the Counter-Reformation campaign and attempts to initiate processes of Catholic confessionalization in East-Central Europe were to a certain extent coordinated by the central authorities of the Roman Catholic Church, and papal nuncios were responsible for it 'in the field'. One can defend the thesis that at the end of the sixteenth and the beginning of the seventeenth century this was a substantial problem for Rome and not only because of the policy toward the Ottoman Empire. This is evidenced, for example, by a survey and analysis of instructions prepared for apostolic nuncios during the pontificate of Clement VIII (1592-1605). From ninety-nine documents of this kind, no less than twenty-five were prepared for papal representatives in order to seek to influence the confessional policy of East-Central European rulers. ${ }^{76}$ Besides the printed sources, a high number of (published and unpublished) relations by nuncios and other papal diplomats from the countries of the region have been preserved, which would allow for the comparative analysis of the state of Counter-Reformation and confessionalization processes in Bohemia and in the Polish-Lithuanian Commonwealth. ${ }^{77}$

Research on the consequences of the Counter-Reformation campaign and of Catholic confessionalization processes does not have to be limited to the territory of the Commonwealth, and the Crowns of St Wenceslas and St Stephen. This is the type of study which corresponds very well with Müller's postulate to construct individual 'research spaces' to compare phenomena in different territories, sometimes distant from each other in geographical space. One interesting example is the research project carried out by Damien Tricoire, and completed by his recently published monograph that presents the circumstances, course and political effects of the confessional policy of re-Catholicization in early modern France, Bavaria and the Commonwealth. ${ }^{78}$

The author conducted a comparative analysis of relations between religion and politics in the selected European space. To this end, he

Konfessionelle Orientierung und politische Landesinteressen in Böhmen und Mähren (bis 1630)', in Ständefreiheit und Staatsgestaltung in Ostmitteleuropa, pp. 229-41.

${ }^{76}$ Die Hauptinstruktionen Clemens' VIII. für die Nuntien und Legaten an den europäischen Fürstenhöfen 1592-1605, 2 vols, ed. Klaus Jaitner, Tübingen, 1984.

77 The literature arising from research on the so called nuncios' relations is extensive, for example Wojciech Tygielski, 'Opinie nuncjuszy apostolskich na temat Polski XVI-XVII w.', PH, 84, 1994, 4, pp. 351-62; idem, Z Rzymu do Rzeczypospolitej. Studia $z$ dziejów nuncjatury apostolskiej w Polsce XVI-XVII w., Warsaw, 1992.

${ }^{78}$ Damien Tricoire, Mit Gott rechnen. Katholische Reform und politisches Kalkül in Frankreich, Bayern und Polen-Litauen, Göttingen, 2013. 
studied the symptoms of re-Catholicization in the spirit of the post-Tridentine reform, and, first of all, the growing significance of the Marian cult which - according to the confessionalization paradigm - was instrumentalized by Catholic monarchies to strengthen their rule. But the author asks if this always had to mean the strengthening of the state. Tricoire was, therefore, interested not only in the processes of Catholic confessionalization developing at a different pace in Bavarian, French and Polish-Lithuanian-Ruthenian societies, but mainly in their political consequences in the mid-seventeenth century. It is obvious that the same means and activities in different situations have different effects. However, discussing the reasons why the pushing forward of Catholic reform in France and Bavaria 'in spite of all obstacles and losses' finally strengthened those states, whereas in the Polish-Lithuanian Commonwealth the state was further weakened 'as an indirect and undesirable long-term consequence of Catholic reform', has proved so interesting that this research - conducted in a rather arbitrarily constructed 'historical space' - can be considered successful. ${ }^{79}$

The selection of the research field made by the author of this book, followed by cognitive success, confirms our conviction that sometimes the specificities of historical regions understood in a traditional way as geographic spaces impedes or prevents the use of certain research paradigms. We believe that with respect to political systems and religious problems studying modernization through confessionalization is such an ineffective approach. ${ }^{80}$ We understand it as a process in which close cooperation between Church officials in a given territory and the ruling secular authorities' structures results, first, in a religious homogenization of the society and a significant strengthening of the state, and, next, the acceleration of the process of its modernization. ${ }^{81}$ It transpires that processes in East-Cen-

79 'trotz aller Wirren und Verwüstungen'; 'als eine indirekte und ungewollte langfristige Konsequenz der Katholischen Reform’, ibid., p. 389.

${ }^{80}$ At least two collections of studies were published, the authors of which referring with competence to the confessionalization paradigm analysed the region of East-Central Europe, but the achieved detailed effects did not result in convincing generalizations: Konfessionalisierung in Ostmitteleuropa. Wirkungen des religiösen Wandels im 16. und 17. Jahrhundert in Staat, Gesellschaft und Kultur, ed. Joachim Bahlcke and Arno Strohmeyer, Stuttgart, 1999, Forschungen zur Geschichte und Kultur des östlichen Mitteleuropa, vol. 7 - here, especially, the study by Winfried Eberhard, 'Voraussetzungen und strukturellen Grundlagen der Konfessionalisierung in Ostmitteleuropa', pp. 89-103; Konfessionelle Formierungsprozesse im frühneuzeitlichen Ostmitteleuropa. Vorträge und Studien, ed. Jörg Deventer, Leipzig, 2006, Berichte und Beiträge des geisteswissenschaftliches Zentrums Geschichte und Kultur Ostmitteleuropas an der Universität Leipzig, vol. 2.

${ }^{81}$ The most important theoretical texts of the authors of confessionalization theory were published in the following collections: Wolfgang Reinhard, Ausgewählte Ab- 
tral Europe, understood in such a way, were initiated, but did not develop, and so did not bring any modernization effects.

Attempts aimed at the Catholic confessionalization of the Polish-Lithuanian-Ruthenia society initiated in the Commonwealth at the end of the sixteenth and the beginning of seventeenth century, in face of strong social resistance not only did not strengthen the monarchy, but did not even bring religious unification or - still more so - any effect of modernization..$^{82}$ The confessional coercion introduced after 1620 in the lands of the Crown of St Wenceslas brought effects in the form of the formal re-Catholicization of the society, but one may have serious doubts as to its depth and durability. Similar attempts of state authorities to implement Catholic confessionalization in the Hungarian lands gradually taken over from Ottoman domination never resulted in their religious homogenization. ${ }^{83}$ It seems that the later modernization processes in these lands had a completely different genesis and they should not be linked with the pursuit of a delayed and only partly effective Catholic confessionalization in the seventeenth century.

The reasons for this delay and ineffectiveness of confessionalization processes in East-Central Europe are easy to explain. A necessary condition for the modernization of a state by confessionalization is, as mentioned above, the cooperation of state administration with the structures of the dominant Church. Where the state could practically do without complex administrative structures - like in the Polish-Lithuanian Commonwealth - and the Catholic Church long strove for the formal restoration of its status as the ruling religion, the success of Catholic confessionalization was simply impossible. And this was not the only example in the modern Europe of the ineffectiveness of confessionalization processes due to the weakness of the state. Decentralization and weak administrative structures were also a decisive element of the lack of success of Evangelical-Reformed confessionalization in the United Provinces of the Northern Netherlands. ${ }^{84}$ In spite of the facts that

handlungen, Berlin, 1997; Heinz Schilling, Ausgewählte Abhandlungen zur europäischen Reformations- und Konfessionsgeschichte, ed. Luise Schorn-Schütte and Olaf Mörke, Berlin, 2002; see also: Interkonfessionalität - Transkonfessionalität - binnenkonfessionelle Pluralität. Neue Forschungen zur Konfessionalisierungsthese, ed. Kaspar von Greyerz et al., Heidelberg, 2003, reviewed by Maciej Ptaszyński, KH, 112, 2005, 2, pp. 130-33.

${ }^{82}$ Kriegseisen, Stosunki wyznaniowe w relacjach państwo-kościót, pp. 576-660.

${ }^{83}$ István Keul, Early Modern Religious Communities in East-Central Europe. Ethnic Diversity, Denominational Plurality, and Corporative Politics in the Principality of Transylvania (1526-1691), Leiden, 2009, pp. 219-70.

${ }^{84}$ Olaf Mörke, “"Konfessionalisierung” als politische-soziales Strukturprinzip? Das Verhältnis von Religion und Staatsbildung in der Republik der Vereinigten 
firstly, in the second half of the seventeenth century Calvinism was not only the religion officially supported and protected by the Dutch state authorities, second, that had a majority over the believers of other Christian confessions, and third, that 'nadere reformatie' ('further reformation' understood as strengthening religious identification and deepening the spiritual life) brought spectacular effects, the Dutch Evangelical-Reformed Church did not obtain the official position of state religion, so the United Provinces of the Northern Netherlands until the very end of their existence remained, in a formal sense, 'a non-confessional state'. ${ }^{85}$

This confirms our conviction that against the European background the tolerant Polish-Lithuanian Commonwealth in the sixteenth and seventeenth century was not, at least with respect to religious relations, a phenomenon that was not comparable to other states ${ }^{86}$ This encourages comparative studies not only in the clearly geographically defined region of East-Central Europe, but also in fields outside this region.

(Translated by Elżbieta Petrajtis-O’Neill)

\section{Summary}

Regional divisions have long since been examined in research on European history and not always from the sole vantage point of historical craftmanship. The inclusion of a territory (tribal, state, national) into a given region possesses, as a rule, important political and ideological implications. On the other hand, relevant scholarly debate should refer to specific problems and at times even to research projects that seek solutions and answers involving the application of comparative studies. This minimal condition for studies about East-Central Europe was introduced as early as 1950 by Oskar Halecki. The usefulness of the regional division of Europe proposed by Halecki was confirmed for East-Central Europe predominantly thanks to studies on the economy, various questions about political systems and the specific political culture of the region. Recently, this assumption was confirmed, while modifying the idea launched by Halecki, by the research proposals formulated by Michael G. Müller, a German historian specializing in the history of East-Central

Niederlande im 16. und 17. Jahrhundert', Tijdschrift voor Sociale Geschiedenis, 16, 1990, 1, pp. 31-60; idem, 'Die politische Bedeutung des Konfessionellen im Deutschen Reich und in der Republik der Vereinigten Niederlande oder: War die Konfessionalisierung ein “Fundamentalvorgang"?', in Der Absolutismus - ein Mythos?, pp. 125-64.

${ }^{85}$ Kriegseisen, Stosunki wyznaniowe w relacjach państwo-kościót, pp. 359-408.

${ }^{86}$ Adam Manikowski, 'C zy siedemnastowieczna Rzeczpospolita była anomalią wśród innych państw europejskich?’, OiRP, 37, 1993, pp. 79-87; Wojciech Tygielski, 'Rzeczpospolita szlachecka: paradoks historii czy europejska norma?', in Tematy polsko-białoruskie. Historia. Literatura. Edukacja, ed. Robert Traba, Olsztyn, 2003, pp. 40-53. 
Europe. The process of distinguishing the region of East-Central Europe has also proved useful in studies on the history of religion from the sixteenth to the eighteenth century. Alongside the economy based on the manor and the serfdom, and the estate-based system featuring the predominance of the nobility, it was precisely the extremely high level of religious and confessional diversity that was one of the most characteristic and permanent features of early modern societies in East-Central Europe: the Polish-Lithuanian Commonwealth, the lands of the Crown of St Wenceslas, and the lands of the Crown of St Stephen.

(Translated by Aleksandra Rodzińska-Chojnowska)

\section{Bibliography}

Der Absolutismus - ein Mythos? Strukturwandel monarchischer Herrschaft in Westund Mitteleuropa (ca. 1550-1700), ed. Ronald G. Asch and Heinz Duchhardt, Cologne: Böhlau, 1996.

Adriányi, Gabriel, 'Die Ausbreitung der Reformation in Ungarn', Ungarn-Jahrbuch, 5, 1973, pp. 66-75.

Aly, Götz, 'Theodor Schieder, Werner Conze oder die Vorstufen der physischen Vernichtung', in Deutsche Historiker im Nationalsozialismus, ed. Winfried Schulze and Otto Gerhard Oexle, Frankfurt am Main: Fischer Taschenbuch, 1999, pp. 163-82.

Augustyniak, Urszula, Historia Polski 1572-1795, Warsaw: Wydawnictwo Naukowe PWN, 2008.

Augustyniak, Urszula, Wazowie i 'królowie rodacy'. Studium władzy królewskiej w Rzeczypospolitej XVII wieku, Warsaw: Wydawnictwo Naukowe Semper, 1999.

Bahlcke, Joachim, 'Calvinism and Estate Liberation Movement in Bohemia and Hungary (1570-1620)', in The Reformation in Eastern and Central Europe, ed. Karin Maag, Aldershot: Scolar Press, 1997, pp. 72-91.

Bahlcke, Joachim, 'Konföderation und Widerstand. Die politische Beziehungen der böhmischen Ständegemeinde', Folia Historica Bohemica, 13, 1990, pp. 235-88.

Bahlcke, Joachim, Regionalismus und Staatsintegration im Widerstreit. Die Länder der Böhmischen Krone im ersten Jahrhundert der Habsburgermonarchie (1526-1619), Munich: Oldenbourg, 1994.

Balázs, Mihály, Early Transylvanian Antitrinitarism (1566-1571). From Servet to Paleologus, Baden-Baden: Koerner, 1996.

Balcárek, Pavel, Kardinál František z Ditrichštejna (1570-1636), Kroměříž: Muzeum Kroměřížska, 1990.

Benda, Kalman, 'Absolutismus und ständischer Widerstand in Ungarn am Anfang des 17. Jahrhunderts', Südostforschung, 33, 1974, pp. 85-124.

Benda, Kalman, 'Die Auswirkung der Lehren Calvins auf die Ideologie des ständischen Widerstandes in Ungarn', Jahrbuch der Gesellschaft für die Geschichte des Protestantismus in Österreich, 110/111, 1994/95, pp. 75-85.

Binder, Ludwig, Grundlagen und Formen der Toleranz in Siebenbürgen bis zur Mitte 
des 17.Jahrhunderts, Cologne and Vienna: Böhlau, 1976, Siebenbürgisches Archiv, vol. 11.

Bömelburg, Hans-Jürgen, 'Zwischen imperialer Geschichte und Ostmitteleuropa als Geschichtsregion. Oskar Halecki und die polnische "jagiellonische Idee"', in Vergangene Größe und Ohnmacht in Ostmitteleuropa. Repräsentationen imperialer Erfahrung in der Historiographie seit 1918, ed. Frank Hadler and Matthias Mesenhöller, Leipzig: Akademische Verlagsanstalt, 2007, pp. 99-133.

Brzechczyn, Krzysztof, Odrębność historyczna Europy Środkowej. Studium metodologiczne, Poznań: Wydawnictwo Fundacji Humaniora, 1998.

Bůžek, Vázlav, Nižši šlechta v politickém systému a kultuře predbělohorských Čech, Praha: Historický ústav Akademie věd České republiky, 1996.

Chodynicki, Kazimierz, 'Geneza równouprawnienia schizmatyków w Wielkim Księstwie Litewskim. Stosunek Zygmunta Augusta do wyznania grecko-wschodniego', Przeglad Historyczny, 22, 1919-1920, pp. 54-135.

Cisek, Janusz, Oskar Halecki. Historyk - Szermierz Wolności, Warsaw: Instytut Pamięci Narodowej - Komisja Ścigania Zbrodni przeciwko Narodowi Polskiemu, 2009.

Csohány, János, 'Die politische Beziehungen von Gábor Bethlen zum reformierten Europa', Jahrbuch für die Geschichte des Protestantismus in Österreich, 110/ 111, 1994/95, pp. 87-98.

Conze, Werner, Ostmitteleuropa. Von der Spätantike bis zum 18. Jahrhundert, ed. and afterword Klaus Zernack, Munich: Beck, 1992, pp. 105-42.

Czermak, Wiktor, Sprawa równouprawnienia schizmatyków i katolików i schizmatyków na Litwie (1432-1563), Cracow: Akademia Umiejętności, 1903.

Daniel, David P., 'Calvinism in Hungary. The Ideological and Ecclesiastical Transition to the Reformed Faith', in Calvinism in Europe 1540-1620, ed. Andrew Pettegree, Alastair Duke and Gillian Lewis, Cambridge: Cambridge University Press, 1994, pp. 205-30.

Daniel, David P., 'The Influence of the Augsburg Confession in South-East Central Europe', The Sixteenth Century Journal, 11, 1980, pp. 99-114.

Daugirdas, Kęstutis, 'Rezeption der Theologie Calvins im Großfürstentum Litauen und Königreich Polen', in Calvin und Calvinismus - europäische Perspektiven, ed. Irene Dingel and Herman J. Selderhuis, Göttingen: Vandenhoeck \& Ruprecht, 2011, pp. 155-70.

David, Zdeněk V., Finding the Middle Way. The Utraquist's Liberal Challenge to Rome and Luther, Washington, DC: Woodrow Wilson Center Press; Baltimore, MD, and London: Johns Hopkins University Press, 2003.

Drabek, Anna Maria, 'Die politische Haltung der böhmischen und mährischen Stände zum Herrscherabsolutismus des 17. und 18. Jahrhunderts. Von der traditionellen ständischen Rechtspositionen zu frühkonstitutionellen Forderungen', in Ständefreiheit und Staatsgestaltung in Ostmitteleuropa. Übernationale Gemeinsamkeiten in der politischen Kultur vom 16.-18. Jahrhundert, ed. Joachim Bahlcke, Hans-Jürgen Bömelburg and Norbert Kersken, Leipzig: Universitätsverlag Leipzig, 1996, pp. 265-82. 
Drabina, Jan, ‘Koegzystencja religii i wyznań w Polsce w latach 1333-1370', Zeszyty Naukowe UJ, Studia Religiologica, 25, 1992, pp. 37-50.

Duchhardt, Heinz, “"Absolutismus” - Abschied von einem Epochenbegriff?', Historische Zeitschrift, 258, 1994, pp. 113-22.

Eberhard, Winfried, 'Entstehungsbedingungen für öffentliche Toleranz am Beispiel des Kuttenberger Religionsfrieden von 1485', Communio viatorum, 29, 1986, pp. 129-54.

Eberhard, Winfried, 'Ständische Strukturen in Ostmitteleuropa. Problemstellungen und Thesen. (Eine vorläufige Diskussionsbilanz)', in Ständefreiheit und Staatsgestaltung in Ostmitteleuropa. Übernationale Gemeinsamkeiten in der politischen Kultur vom 16.-18. Jahrhundert, ed. Joachim Bahlcke, Hans-Jürgen Bömelburg and Norbert Kersken, Leipzig: Universitätsverlag Leipzig, 1996, pp. 311-18.

Eberhard, Winfried, 'Voraussetzungen und strukturellen Grundlagen der Konfessionalisierung in Ostmitteleuropa', in Konfessionalisierung in Ostmitteleuropa. Wirkungen des religiösen Wandels im 16. und 17. Jahrhundert in Staat, Gesellschaft und Kultur, ed. Joachim Bahlcke and Arno Strohmeyer, Stuttgart: Steiner, 1999, Forschungen zur Geschichte und Kultur des östlichen Mitteleuropa, vol. 7, pp. 89-103.

Eberhard, Winfried, 'Zu den politischen und ideologischen Bedingungen öffentlicher Toleranz. Der Kuttenberger Religionsfrieden', Studia Germano-Polonica, 1,1992, pp. 101-18.

Etzemüller, Thomas, Sozialgeschichte als politische Geschichte. Werner Conze und die Neuorientierung der westdeutschen Geschichtswissenschaft nach 1945, Munich: Oldenbourg, 2001.

Evans, Robert J.W., 'Calvinism in East Central Europe. Hungary and her Neighbours', in International Calvinism 1541-1715, ed. Menna Prestwich, Oxford: Clarendon Press, 1985, pp.167-96.

Evans, Robert J. W., The Making of the Habsburg Monarchy, 1550-1700: An Interpretation, Oxford, 1979.

Fata, Márta, Ungarn, das Reich der Stephanskrone, im Zeitalter der Reformation und Konfessionalisierung. Multiethnizität, Land und Konfession 1500 bis 1700, ed. Franz Brendle and Anton Schindling, Münster: Aschendorff, 2000.

Geremek, Bronisław, ‘Polska w geografii kulturowej średniowiecznej Europy’, in Kultura Polski średniowiecznej X-XIII w., ed. Jerzy Dowiat, Warsaw: Państwowy Instytut Wydawniczy, 1985, pp. 8-26.

Geremek, Bronisław, ‘Więź i poczucie wspólnoty w średniowiecznej Europie’, in Dziesięć wieków Europy. Studia z dziejów kontynentu, ed. Janusz Żarnowski, Warsaw: Czytelnik, 1983, pp. 19-81.

Geremek, Bronisław, 'Uwagi o pojęciu “mas” w historii społecznej', Roczniki Humanistyczne, 34, 1986, 2, pp. 199-209.

Gmiterek, Henryk, 'Die Rezeption reformatorischer Ideen und religiöser Widerstandstheorien innerhalb der polnischen Eliten', in Ständefreiheit und Staatsgestaltung in Ostmitteleuropa. Übernationale Gemeinsamkeiten in der politischen Kultur vom 16.-18. Jahrhundert, ed. Joachim Bahlcke, Hans-Jürgen Bömelburg and Norbert Kersken, Leipzig: Universitätsverlag Leipzig, 1996, pp. 217-27. 
Grala, Hieronim, 'Kołpak Witoldowy czy czapka Monomacha? Dylematy wyznawców prawosławia w monarchii ostatnich Jagiellonów', in Katolicyzm w Rosji i prawostawie w Polsce (XI-XX w.), ed. Juliusz Bardach and Teresa Chynczewska-Hennel, Warsaw: Upowszechnianie Nauki - Oświata 'UN-O', 1997, pp. 51-67.

'Granice' $i$ 'pogranicza' $w$ badaniach historycznych $i$ antropologicznych, ed. Paweł Figurski and Maksymilian Sas, Warsaw: Studenckie Koło Naukowe Historyków Uniwersytetu Warszawskiego and Instytut Historyczny Uniwersytetu Warszawskiego, 2012.

Grodecki, Roman, 'Do genezy artykułu “o wypowiedzeniu posłuszeństwa"', Przeglad Wspólczesny, 16, 1937, 61, pp. 185-205.

Grześkowiak-Krwawicz, Anna, Regina libertas. Wolność w polskiej myśli politycznej XVIII wieku, Gdańsk: słowo/obraz terytoria, 2006.

Hahn, Peter-Michael, Calvinismus und Staatsbildung. Brandenburg-Preußen im 17. Jahrhundert, in Territorialstaat und Calvinismus, ed. Meinrad Schaab, Stuttgart: Kohlhammer, 1993, pp. 239-69.

Halecki, Oskar, Historia Europy - jej granice i podziały, transl.Jan M. Kłoczowski, ed. Hubert Łaszkiewicz, introduction Jerzy Kłoczowski, Lublin: Instytut Europy Środkowo-Wschodniej, 1994, Biblioteka Europy Środkowo-Wschodniej, vol. 1 (2nd edn Lublin, 2002).

Halecki, Oskar, The Limits and Divisions of European History, New York: Sheed \& Ward, 1950.

Die Hauptinstruktionen Clemens' VIII. für die Nuntien und Legaten an den europäischen Fürstenhöfen 1592-1605, 2 vols, ed. Klaus Jaitner, Tübingen: Niemeyer, 1984.

Henshall, Nicholas, The Myth of Absolutism. Change and Continuity in Early Modern European Monarchy, London and New York: Longman, 1992.

Hintze, Otto, 'Kalvinismus und Staatsräson in Brandenburg zu Beginn des 17. Jahrhunderts', Historische Zeitschrift, 144, 1931, pp. 229-86.

Histoire de la Transylvanie, ed. Béla Köpeczi et al., Budapest: Akadémiai Kiadó, 1989, pp. 280-85.

Honzal, Josef, 'Rekatolizace v Čechách. Její historický smysl a význam', Sbornik historický, 37, 1990, pp. 37-91.

Höpfl, Harro, The Christian Polity of John Calvin, Cambridge: Cambridge University Press, 1982, pp. 153-58.

Hroch, Miroslav, 'Central Europe. The Rise and Fall of an Historical Region', in Central Europe. Core or Periphery?, ed. Christopher Lord, Copenhagen: Copenhagen Business School Press, 2000, pp. 21-34.

Hrubý, František, 'Luterství a kalvinismus na Moravě před Bílou horou', Český časopis historický, 41, 1935, pp. 1-40, 237-68.

Hrubý, František, 'Luterství a novoutrakvismus v českých zemích v 16. a 17. století', Český časopis historický, 45, 1939, pp. 31-44.

Hubatsch, Walther, Das Zeitalter des Absolutismus 1600-1789, Braunschweig: Westermann, 1962.

Interkonfessionalität - Transkonfessionalität - binnenkonfessionelle Pluralität. Neue For- 
schungen zur Konfessionalisierungsthese, ed. Kaspar von Greyerz et al., Heidelberg: Gütersloher Verlagshaus, 2003.

Iwańczak, Wojciech, 'Katolicy i husyci w czasach Jerzego z Podiebradu', in Stosunki międzywyznaniowe w Europie Środkowej i Wschodniej w XIV-XVII wieku, ed. Marian Dygo, Sławomir Gawlas and Hieronim Grala, Warsaw: DiG, 2002, pp. 25-37.

Iwańczak, Wojciech, 'Kościół w Czechach w XVI w. - dezintegracja i łączność', Przeglad Humanistyczny, 50, 2006, 3, pp. 21-30.

Janeczek, Andrzej, 'Ethnicity, Religious Disparity and the Formation of the Multicultural Society of Red Ruthenia in the late Middle Ages', in On the Frontier of Latin Europe. Integration and Segregation in Red Ruthenia, 1350-1600, ed. Thomas Wünsch and Andrzej Janeczek, Warsaw: Institute of Archaeology and Ethnology of the Polish Academy of Sciences, 2004, pp. 15-46.

Jedlicki, Jerzy, Jakiej cywilizacji Polacy potrzebuja. Studia z dziejów idei i wyobraźni XIX wieku, Warsaw: Państwowe Wydawnictwo Naukowe, 1988, Polska XIX i XX Wieku. Dzieje Społeczne, ed. Janusz Żarnowski.

Kamieniecki, Witold, 'Ograniczenia wyznaniowe w prawodawstwie Wielkiego Księstwa Litewskiego', Przegląd Historyczny, 13, 1911, 3, pp. 268-82.

Keul, István, Early Modern Religious Communities in East-Central Europe. Ethnic Diversity, Denominational Plurality, and Corporative Politics in the Principality of Transylvania (1526-1691), Leiden: Brill, 2009, pp. 219-70.

Kiaupa, Zigmantas, Jūratė Kiaupienè and Albinas Kuncevičius, The History of Lithuania before 1795, Vilnius: Lithuanian Institute of History, 2000.

Kingdon, Robert M., 'Calvinism and Resistance Theory 1550-1580', in The Cambridge History of Political Thought, 1450-1700, ed. James H. Burns, Cambridge: Cambridge University Press, 1991, pp. 193-218.

Kłoczowski, Jerzy, Europa Środkowowschodnia w historiografii krajów regionu, Lublin: Instytut Europy Środkowo-Wschodniej, 1993, Materiały Instytutu Europy Środkowo-Wschodniej [Materials of the Institute of East-Central Europe], vol. 5.

Kłoczowski, Jerzy, Młodsza Europa. East-Central Europe w kręgu cywilizacji chrześcijańskiego średniowiecza, Warsaw: Państwowy Instytut Wydawniczy, 1998.

Kłoczowski, Jerzy, ‘Oskar Halecki i jego walka o miejsce Polski w Europie’, in Z dziejów polityki i dyplomacji polskiej. Studia poświęcone pamięci Edwarda hr. Raczyńskiego, Prezydenta Rzeczypospolitej na wychodźstwie, ed. Henryk Bułhak, Warsaw: Wydawnictwo Sejmowe, 1994, pp. 397-406.

Kohler, Alfred, 'Ferdinand I and the Estates. Between Confrontation and Cooperation, 1521-1564', in Crown, Church and Estates. Central European Politics in the Sixteenth and Seventeenth Centuries, ed. Robert J. W. Evans and Trevor V. Thomas, New York: St. Martin's Press; London: Macmillan, 1991, pp. 48-57.

Konfessionalisierung in Ostmitteleuropa. Wirkungen des religiösen Wandels im 16. und 17. Jahrhundert in Staat, Gesellschaft und Kultur, ed. Joachim Bahlcke and Arno Strohmeyer, Stuttgart: Steiner, 1999, Forschungen zur Geschichte und Kultur des östlichen Mitteleuropa, vol. 7.

Konfessionelle Formierungsprozesse im frühneuzeitlichen Ostmitteleuropa. Vorträge und Studien, ed. Jörg Deventer, Leipzig: Geisteswissenschaftliches Zentrum 
Geschichte und Kultur Ostmitteleuropas, 2006, Berichte und Beiträge des geisteswissenschaftliches Zentrums Geschichte und Kultur Ostmitteleuropas an der Universität Leipzig, vol. 2.

Kornat, Marek, 'Historyk Europy Środkowo-Wschodniej. Oskar Halecki (18911973) w nauce i życiu Polski', in Historik v proměnách doby a prostředí 20. století, ed. Jiř́i Hanuš and Radomír Vlček, Brno: Matice moravská, 2009, pp. 305-38.

Kriegseisen, Wojciech, 'Polski przekład XX rozdziału czwartej części księgi Institutio Christianae religionis Jana Kalwina', Odrodzenie i Reformacja w Polsce, 50, 2007, pp. 101-13.

Kriegseisen, Wojciech, Stosunki wyznaniowe w relacjach państwo-kościót między reformacja a oświeceniem (Rzesza Niemiecka - Niderlandy Pótnocne - Rzeczpospolita polsko-litewska), Warsaw: Wydawnictwo Naukowe Semper, 2010.

Król a prawo stanów do oporu, ed. Mariusz Markiewicz, Edward Opaliński and Ryszard Skowron, Cracow: Zamek Królewski na Wawelu, 2010.

Kuźma, Erazm, Mit Orientu i kultury Zachodu w literaturze XIX i XX wieku, Szczecin: Wydawnictwa Naukowe WSP, 1980.

Lepszy, Kazimierz, Rzeczpospolita Polska w dobie sejmu inkwizycyjnego (1589-1592), Cracow: Polska Akademia Umiejętności, 1939.

Liedke, Marzena, 'Świadomość narodowa i udział szlachty oraz możnych ruskich Wielkiego Księstwa Litewskiego w kształtowaniu narodu szlacheckiego Rzeczypospolitej w drugiej połowie XVI wieku', in Europa Orientalis. Polska i jej wschodni sasiedzi od średniowiecza po wspótczesność. Studia i materiały ofiarowane Profesorowi Stanisławowi Alexandrowiczowi w 65. rocznice urodzin, ed. Zbigniew Karpus, Tadeusz Kempa and Dorota Michaluk, Toruń: Uniwersytet Mikołaja Kopernika, 1996, pp. 135-44.

Machilek, František, 'Böhmen', in Die Territorien des Reichs im Zeitalter der Reformation und Konfessionalisierung. Land und Konfession 1500-1650, ed. Anton Schindling and Walter Ziegler, 7 vols, Münster: Aschendorff, 1989-97, vol.1, pp. 134-52.

Maciszewski, Jarema, Wojna domowa w Polsce (1606-1609). Studium z dziejów walki przeciw kontrreformacji. Część I. Od Stężycy do Janowca, Wrocław: Zakład Narodowy im. Ossolińskich, 1960.

Manikowski, Adam, 'Czy siedemnastowieczna Rzeczpospolita była anomalią wśród innych państw europejskich?’, Odrodzenie i Reformacja w Polsce, 37, 1993, pp. 79-87.

Manteuffel, Tadeusz, 'Metoda oznaczania granic w geografii historycznej', in Księga pamiattkowa ku uczczeniu dwudziestopięcioletniej działalności naukowej prof. Marcelego Handelsmana, Warsaw: [n. pub.], 1929, pp. 221-28.

Michalski, Jerzy, 'Sarmatyzm a europeizacja Polski w XVIII wieku', in idem, Studia historyczne z XVIII i XIX wieku, 2 vols, Warsaw: Stentor, 2007, vol. 2: Ideologia. Nauka. Historiografia, pp. 7-36.

Mikulec, Jiří, Pobělohorská rekatolizace v českých zemích, Praha: Státní pedagogické nakladatelství, 1992.

Molnár, Amadeo, 'Reformovaný svět a bratrská šlechta', Křestanská revue, 38, 1971, pp. 140-42. 
Mörke, Olaf, “"Konfessionalisierung” als politische-soziales Strukturprinzip? Das Verhältnis von Religion und Staatsbildung in der Republik der Vereinigten Niederlande im 16. und 17. Jahrhundert', Tijdschrift voor Sociale Geschiedenis, 16, 1990, 1, pp.31-60.

Mörke, Olaf, 'Die politische Bedeutung des Konfessionellen im Deutschen Reich und in der Republik der Vereinigten Niederlande oder: War die Konfessionalisierung ein “Fundamentalvorgang"?', in Der Absolutismus - ein Mythos? Strukturwandel monarchischer Herrschaft in West- und Mitteleuropa (ca.1550-1700), ed. Ronald G. Asch and Heinz Duchhardt, Cologne: Böhlau, 1996, pp. 125-64.

Mout, M.E.H. Nicolette, 'Die politische Theorie in der Bildung der Eliten. Die Lipsius-Rezeption in Böhmen und Ungarn', in Ständefreiheit und Staatsgestaltung in Ostmitteleuropa. Übernationale Gemeinsamkeiten in der politischen Kultur vom 16.-18. Jahrhundert, ed. Joachim Bahlcke, Hans-Jürgen Bömelburg and Norbert Kersken, Leipzig: Universitätsverlag Leipzig, 1996, pp. 243-64.

Müller, Michael G., ‘Gdzie i kiedy była Europa Środkowo (Wschodnia)?’, transl. Jacek Serwański, in idem, Zrozumieć polska historię, Poznań: Wydawnictwo Poznańskie, 2012, pp. 90-105.

Müller, Michael G., 'Where and When was (East) Central Europe?', in Domains and Divisions of European History, ed. Jóhann P. Árnason and Natalie J. Doyle, Liverpool: Liverpool University Press, 2010, pp. 112-25.

Müller, Michael G., Zweite Reformation und städtische Autonomie im Königlichen Preußen. Danzig, Elbing und Thorn in der Epoche der Konfessionalisierung (15571660), Berlin: Akademie Verlag, 1997.

Müller, Michael G., and Cornelius Torp, 'Conceptualising Transnational Spaces of History', European Review of History - Revue européenne d'histoire, 16, 2009, 5, pp. 609-17.

Murdock, Graeme, Calvinism on the frontier 1600-1660. International Calvinism and the Reformed Church in Hungary and Transylvania, Oxford: Clarendon Press, 2000.

Myśliwski, Grzegorz, 'Powstanie i rozwój granicy liniowej na Mazowszu (XII-poł. XVI w.)', Kwartalnik Historyczny, 101, 1994, 3, pp. 3-24.

Noga, Zdzisław, 'Zróżnicowanie etniczne i wyznaniowe mieszczaństwa krakowskiego w XVI wieku', in Między Zachodem a Wschodem. Etniczne, kulturowe i religijne pogranicza Rzeczypospolitej w XVI-XVIII wieku, ed. Krzysztof Mikulski and Agnieszka Zielińska-Nowicka, Toruń: Mado, 2005, pp. 121-28.

Oestreich, Gerhard, Geist und Gestalt des frühmodernen Staates. Ausgewählte Aufsätze, Berlin: Duncker \& Humblot, 1969.

Opaliński, Edward, Kultura polityczna szlachty polskiej w latach 1587-1652. System parlamentarny a społeczeństwo obywatelskie, Warsaw: Wydawnictwo Sejmowe, 1995.

Oskar Halecki i jego wizja Europy, ed. Małgorzata Dąbrowska, 3 vols, Warsaw and Łódź: Instytut Pamięci Narodowej - Komisja Ścigania Zbrodni przeciwko Narodowi Polskiemu, 2012-14, vol. 1 .

Pánek, Jaroslav, 'The Religious Question and the Political System of Bohemia before and after the Battle of the White Mountain', in Crown, Church and Estates. Central European Politics in the Sixteenth and Seventeenth Centuries, ed. Robert J.W. 
Evans and Trevor V. Thomas, New York: St. Martin's Press; London: Macmillan, 1991, pp. 129-48.

Pánek, Jaroslav, Stavovská opozice a její zápas s Habsburky 1547-1577. K politické krizi feudální třídy v predbělohorském českém státě, Praha: Academia, 1982.

Papée, Fryderyk, 'O przywileju mielnickim dla senatu z r. 1501', in Księga pamiątkowa ku czci Oswalda Balzera, ed. Władysław Abraham et al., 2 vols, Lviv: [n. pub.], 1925, vol. 2, pp.173-87.

Péter, Katalin, 'Hungary', in The Reformation in National Context, ed. Bob Scribner, Roy Porter and Mikuláš Teich, Cambridge: Cambridge University Press, 1994, pp. 155-67.

Pettegree, Andrew, 'The Spread of Calvin's Thought', in The Cambridge Companion to John Calvin, ed. Donald K. McKim, Cambridge: Cambridge University Press, 2004, pp. 207-24.

Pogranicza kulturowe w Europie średniowiecznej. Słowianie i ich sasiedzi, ed. Kazimierz Grążawski and Marek Dulinicz, Brodnica, Warsaw and Olsztyn: Multi, 2012.

Pomian, Krzysztof, 'L’Europe Centrale. Essai de définition', Revue germanique internationale, 1, 1994, pp.9-23.

Ptaszyński, Maciej, 'Zwischen Gemeinwohl und Staatsräson. Das Widerstandsrecht in den Ständedebatten der polnisch-litauischen Republik im 16. Jahrhundert', in Frühneuzeitliche Reiche in Europa. Empires in Early Modern Europe, ed. Tomasz Gromelski, et al., Wiesbaden: Harrassovitz, 2016, pp. 67-87.

Reinerth, Karl, Die Gründung der evangelischen Kirchen in Siebenbürgen, Cologne and Vienna: Böhlau, 1979, Studia Transylvanica, vol. 5.

Rekatolizace v českých zemích. Sborník prríspěvků z konference v Jičíně konané 10. zárí 1993, ed. Jindřich Francek, Pardubice: Městský úřad Jičín, 1995.

Révész, László, 'Die helvetische Reformation in Ungarn', Ungarn-Jahrbuch, 4, 1972, pp. 72-100.

Die Reformation und ihre Wirkungsgeschichte in der Slowakei. Kirchen- und konfessionsgeschichtliche Beiträge, ed. Karl Schwarz and Peter Švorc, Vienna: Evangelischer Presseverband, 1996.

Romanowicz, Wiesław, 'Pogranicze jako przedmiot badań społecznych', Rozprawy Naukowe Państwowej Szkoły Wyższej im. Papieża Jana Pawła II w Białej Podlaskiej, 1, 2007, pp. 87-97.

Russocki, Stanisław, 'Monarchie stanowe środkowo-wschodniej Europy XV-XVII wieku', Kwartalnik Historyczny, 84, 1977, 1, pp. 73-92.

Sattler, Rolf-Joachim, Europa. Geschichte und Aktualität des Begriffes, Braunschweig: Limbach, 1971, Schriftenreihe des Internationalen Schulbuchinstituts, vol. 16. Schramm, Gottfried, 'Polen, Böhmen, Ungarn. Übernationale Gemeinsamkeiten in der politischen Kultur des späten Mittelalters und der frühen Neuzeit', Przeglad Historyczny, 76, 1985, 3, pp. 417-37.

Schramm, Gottfried, 'Polen - Böhmen - Ungarn. Übernationale Gemeinsamkeiten in der politischen Kultur des späten Mittelalters und der frühen Neuzeit', in Ständefreiheit und Staatsgestaltung in Ostmitteleuropa. Übernationale Gemeinsamkeiten in der politischen Kultur vom 16.-18. Jahrhundert, ed. Joachim 
Bahlcke, Hans-Jürgen Bömelburg and Norbert Kersken, Leipzig: Universitätsverlag Leipzig, 1996, pp. 13-38.

Schramm, Gottfried, 'Polen - Böhmen - Ungarn. Übernationale Gemeinsamkeiten in der politischen Kultur im 16.-18. Jahrhundert', in Crown, Church and Estates. Central European Politics in the Sixteenth and Seventeenth Centuries, ed. Robert J.W. Evans and Trevor V. Thomas, New York: St. Martin's Press; London: Macmillan, 1991, pp.176-95.

Schramm, Gottfried, Polska w dziejach Europy Środkowej. Studia, transl. Ewa Płomińska-Krawiec, Poznań: Wydawnictwo Poznańskie, 2010.

Schulze, Winfried, 'Estates and the Problem of Resistance in Theory and Practice in the Sixteenth and Seventeenth Centuries', in Crown, Church and Estates. Central European Politics in the Sixteenth and Seventeenth Centuries, ed. Robert J.W. Evans and Trevor V. Thomas, New York: St. Martin's Press; London: Macmillan, 1991, pp. 158-75.

Skinner, Quentin, The Foundations of Modern Political Thought, 12nd edn, 2 vols, Cambridge: Cambridge Univeristy Press, 2005, vol. 2: The Age of Reformation, pp. 302-48.

Sobieski, Wacław, 'Król czy tyran? Idee rokoszowe a różnowiercy za czasów Zygmunta Augusta', Reformacja w Polsce, 4, 1925, pp. 1-14.

Sobolewski, Ludwik, and Wacław Uruszczak, 'Artykuły mielnickie z roku 1501', Czasopismo Prawno-Historyczne, 42, 1990, pp.31-61.

Stankiewicz, Władysław J., Politics and Religion in Seventeenth Century France. A Study of Political Ideas from the Monarchomachs to Bayle, as Reflected in the Toleration Controversy, Berkeley: University of California Press, 1960.

Stevenson Jr., William R., 'Calvin and Political Issues', in The Cambridge Companion to John Calvin, ed. Donald K. McKim, Cambridge: Cambridge Univeristy Press, 2004, s. 173-87.

Stobiecki, Rafał, ‘Twórczość emigracyjna Oskara Haleckiego (1891-1973). Próba charakterystyki', in Studia z dziejów Polski i Europy w XIX i XX wieku. Księga dedykowana Profesorowi Piotrowi Stanisławowi Wandyczowi, ed. Janusz Faryś, Roman Nir and Marek Szczerbiński, Gorzów Wielkopolski: Zamiejscowy Wydział Kultury Fizycznej Poznańskiej AWF, 2004, pp. 581-92.

Strzelecki, Adam, 'Udział i rola różnowierstwa w rokoszu Zebrzydowskiego (1606-1607)', Reformacja w Polsce, 7/8, 1935/36, pp. 101-84.

Szady, Bogumił, Geografia struktur religijnych $i$ wyznaniowych $w$ Koronie w II połowie XVIII wieku, Lublin: Wydawnictwo KUL, 2010, pp. 48-108.

Szakály, Ferenc, 'Türkenherrschaft und Reformation in Ungarn um die Mitte des 16. Jahrhunderts', in Etudes Historiques Hongroises, vol. 2, ed. Ferenc Glatz and Ervin Pamlényi, Budapest: Akadémiai Kiadó, 1985, pp. 437-59.

Szücs, Jenő, Les trois Europes, introduction Fernand Braudel, Paris: L'Harmattan, 1985.

Szücs, Jenő, ‘The Three Historical Regions of Europe', Acta Historica Academiae Scientiarum Hungaricae, 29, 1983, 2/4, pp. 131-84.

Szűcs, Jenő, Trzy Europy, transl. Jan M. Kłoczowski, scientific ed. Hubert Łaszkiewicz, 
introduction Jerzy Kłoczowski, Lublin: Instytut Europy Środkowo-Wschodniej, 1995, Biblioteka Europy Środkowo-Wschodniej, vol. 2, pp. 29-34.

Szűcs, Jenő, ‘Vázlat Európa három történeti régiójáról', Történelmi Szemle, 1981, 3 , pp. 313-59.

Szujski, Józef, 'Artykuł o wypowiedzeniu posłuszeństwa. Przyczynek do dziejów konstytucji polskiej', in idem, Opowiadania i roztrząsania, vol. 3, Cracow: nakładem rodziny Józefa Szujskiego, 1888, pp. 338-60, Dzieła Józefa Szujskiego, series 2, vol. 7 .

Śliwa, Tadeusz, 'Kościół prawosławny w państwie litewskim w XIII-XIV wieku', in Chrzest Litwy. Geneza, przebieg, konsekwencje, ed. Marek T. Zahajkiewicz, Lublin: Redakcja Wydawnictw Katolickiego Uniwersytetu Lubelskiego, 1990, pp.15-32.

Tazbir, Janusz, Polskie przedmurze chrześcijańskiej Europy. Mity a rzeczywistość historyczna, Warsaw: Interpress, 1987.

Trencsényi, Balazs, 'Patriotism and Elect Nationhood in Early Modern Hungarian Political Discourse', in Whose Love of Which Country? Composite States, National Histories and Patriotic Discourses in Early Modern East Central Europe, ed. Balazs Trencsényi and Marton Zászkaliczky, Leiden and Boston, MA: Brill, 2010, pp. 499-544.

Tricoire, Damien, Mit Gott rechnen. Katholische Reform und politisches Kalkül in Frankreich, Bayern und Polen-Litauen, Göttingen: Vandenhoeck \& Ruprecht, 2013.

Tworek, Stanisław, Działalność oświatowo-kulturalna kalwinizmu małopolskiego (połowa XVI - połowa XVIII w.), Lublin: Wydawnictwo Lubelskie, 1970.

Tygielski, Wojciech, 'Opinie nuncjuszy apostolskich na temat Polski XVIXVII w.', Przeglad Historyczny, 84, 1994, 4, pp. 351-62.

Tygielski, Wojciech, 'Rzeczpospolita szlachecka: paradoks historii czy europejska norma?', in Tematy polsko-białoruskie. Historia. Literatura. Edukacja, ed. Robert Traba, Olsztyn: Wspólnota Kulturowa 'Borussia', 2003, pp. 40-53.

Tygielski, Wojciech, Z Rzymu do Rzeczypospolitej. Studia z dziejów nuncjatury apostolskiej w Polsce XVI-XVII w., Warsaw: Historia pro Futuro, 1992.

Válka, Josef, 'Die "Politiques”. Konfessionelle Orientierung und politische Landesinteressen in Böhmen und Mähren (bis 1630)', in Ständefreiheit und Staatsgestaltung in Ostmitteleuropa. Übernationale Gemeinsamkeiten in der politischen Kultur vom 16.-18. Jahrhundert, ed. Joachim Bahlcke, Hans-Jürgen Bömelburg and Norbert Kersken, Leipzig: Universitätsverlag Leipzig, 1996, pp. 229-41.

Válka, Josef, 'Tolerance, či koexistence? (K povaze soužití různých náboženských vyznání v českých zemích v 15. až 17. století)', Studia Comeniana et historica, 18, 1988, 35, pp. 63-75.

Vybíral, Zdeněk, Politické komunikace aristokratické společnosti českých zemí na počátku novověku, České Budějovice: Historický ústav Jihočeské univerzity, 2005.

Wandycz, Piotr S., Cena wolności. Historia Europy Środkowo-Wschodniej od średniowiecza do współczesności, transl. Tomasz Wyrozumski, Cracow: Znak, 1995.

Wandycz, Piotr S., O czasach dawniejszych i bliższych. Studia z dziejów Polski i Europy Środkowo-Wschodniej, Poznań: Wydawnictwo Poznańskie, 2009.

Wandycz, Piotr S., 'Oskar Halecki i jego koncepcja Europy Środkowo-Wschodniej', Rocznik Instytutu Europy Środkowo-Wschodniej, 5, 2007, pp. 45-51. 
Wandycz, Piotr S., The Price of Freedom. A History of East Central Europe from Middle Ages to the Present, London and New York: Routledge, 1992.

Wierzbicki, Andrzej, Europa w polskiej myśli historycznej i politycznej XIX i XX wieku, Warsaw: Centrum Europejskie Natolin and Wydawnictwo Trio, 2009, pp. 20-21.

Wisner, Henryk, 'W imię praw i zwyczajów, czyli wbrew nim. Rokosz Zebrzydowskiego 1606-1607', in Król a prawo stanów do oporu, ed. Mariusz Markiewicz, Edward Opaliński and Ryszard Skowron, Cracow: Zamek Królewski na Wawelu, 2010, pp. 209-21.

Wolff, Larry, Inventing Eastern Europe. The Map of Civilization on the Mind of the Enlightenment, Stanford, CA: Stanford University Press, 1994.

Wolgast, Eike, Die Religionsfrage als Problem des Widerstandsrechts im 16. Jahrhundert, Heidelberg: Winter, 1980.

Wyrozumski, Jerzy, 'Od ius resistendi do ius de non praestanda oboedientia w Polsce', in Świat, Europa, mała ojczyzna. Studia ofiarowane profesorowi Stanisławowi Grodziskiemu w 80-lecie urodzin, ed. Marian Małecki, Bielsko-Biała: Wyższa Szkoła Administracji, 2009, pp. 155-64.

Yates, Frances A., The Rosicrucian Enlightenment, London and Boston, MA: Routledge, 1972.

Yates, Frances A., Rozenkruciánské osvícenství, transl. Martin Konvička, Praha: Pragma, 2000.

Zaremska, Hanna, Żydzi w średniowiecznej Polsce. Gmina krakowska, Warsaw: Instytut Historii PAN, 2011.

Zeeden, Ernst W., 'Calvins Einwirkung auf die Reformation in Polen-Litauen. Eine Studie über den Reformator Calvin im Spiegel seiner polnischen Korrespondenten', in Syntagma Friburgense. Historische Studien Hermann Aubin dargebracht zum 70. Geburtstag am 23.12. 1955, ed. Manfred Hellmann, Hans Thieme and Walter Wiora, Lindau and Konstanz: Thorbecke, 1956, pp. 329-59.

Zernack, Klaus, ‘Główne problemy historii północno-wschodniej Europy’, Zapiski Historyczne, 50, 1985, 4, pp. 25-38.

Zernack, Klaus, Osteuropa. Eine Einführung in seine Geschichte, Munich: Beck, 1977. Znamierowska-Rakk, Elżbieta, 'Pojęcie i tożsamość Europy Środkowo-Wschodniej w historiografii makroregionu i opinie elit Zachodu', Studia z Dziejów Rosji i Europy Środkowo-Wschodniej, 45, 2010, pp. 5-20.

Biography: Wojciech Kriegseisen - Professor at the Tadeusz Manteuffel Institute of History of the Polish Academy of Sciences and its Director; the head of the Early Modern Studies Department; he specializes in research on the political culture of the Polish-Lithuanian Commonwealth in the eighteenth century and on confessional relations in the early modern Polish state against the European background. E-mail: wkriegseisen@ihpan.edu.pl. 